\title{
Materieelstrafrechtelijke elementen van mensenhandel in het Belgisch strafrecht ${ }^{\mathrm{I}}$
}

\author{
Analyse en evaluatie vanuit strafrechtelijk beleids- en \\ internationaalrechtelijk perspectief
}

Gert Vermeulen²

I Inleiding

Deze bijdrage strekt er in essentie toe de Belgische materieelrechtelijke strafwetgeving inzake mensenhandel, zoals indringend gewijzigd door de 'nieuwe'

I Deze bijdrage is onder meer geënt op evaluatieonderzoek met betrekking tot het Belgisch mensenhandelbeleid (G. Vermeulen, Mensenhandelbeleid in België. Satus questionis, evaluatie en toekomstopties, 2006, Brussel, Koning Boudewijnstichting, Ioo p.; G. Vermeulen, La politique belge en matière de traite des êtres humains. Etat des lieux, évaluation et options futures, 2006, Brussel, Fondation Roi Baudouin, 96 p.). De tekst leunt daarnaast op diverse andere bijdragen van auteur inzake mensenhandel, te weten: G. Vermeulen, 'Mensenhandel met het oog op seksuele exploitatie. Analyse en evaluatie van de wet van Io augustus 2005 vanuit strafrechtelijk beleids- en internationaalrechtelijk perspectief', in: A. Masset, G. Coco, S. Corneille, S. De Decker, F. Gazan, S. Louwette, G. Vermeulen, I. Wattier (ed.), La poursuite et le traitement des auteurs d'infractions à caractère sexuel. De vervolging en behandeling van daders van seksuele misdrijven, Les dossiers de la Revue de Droit Pénal et de Criminologie, nr. I5, 2009, Brussel, La Charte, I6I-I76; randnummers I-27 van G. Vermeulen en L. Arnou, 'Nieuwe Belgische strafwetgeving tegen mensenhandel, mensensmokkel en huisjesmelkerij. Context en verkenning van de Wet van Io augustus 2005', in: Strafrecht en strafprocesrecht, XXXIIste postuniversitaire cyclus Willy Delva, 2005-2006, L. Arnou, J. Delmulle, A. De Nauw, C. De Roy, F. Deruyck, S. Guenter, L. Huybrechts, I. Mennes, J. Meese, B. Spriet, M. Sterkens, G. Stessens, P. Traest, C. Van Den Wyngaert, S. Vandromme, G. Vermeulen, R. Verstraeten (ed.), Mechelen, Gandaius, Wolters Kluwer, 2006, 53-Io6; G. Vermeulen (ed.), Betaalseksrecht. Naar regulering of legalisering van niet-problematische prostitutie?, Antwerpen-Apeldoorn, 2007, Maklu, 6r6 p.; G. Vermeulen, 'Matroesjka's: tien jaar later. Repressie en controle als speerpunten van het vernieuwde mensenhandelbeleid?', Panopticon, 2005, nr. 2, I-IO; G. Vermeulen, 'International Trafficking in Women and Children', Revue internationale de droit pénal, 200I, nrs. 3-4, 837-89o.

2 Gert Vermeulen is hoogleraar strafrecht aan de Universiteit Gent en Directeur van het Institute for International Research on Criminal Policy (IRCP). 
Mensenhandelwet van Io augustus $2005^{3}$ (de aanvankelijke dateerde van I3 april I995) ${ }^{4}$, kritisch te analyseren en te evalueren.

Daarbij is voor een breed perspectief gekozen, dat het juridisch-technische niveau van de materieelstrafrechtelijke bepalingen en de toepassing ervan in de rechtspraktijk overstijgt. Materieel strafrecht is immers het resultaat van strafbaarstellings- (en sanctionerings)beleid, dat vandaag bovendien sterk wordt beïnvloed door internationale en Europese beleidstendensen of -imperatieven. Het gehanteerde analyse- en evaluatiekader is bijgevolg het Belgische strafrechtelijk beleid inzake mensenhandel én mensensmokkel (het vandaag vereiste materieelstrafrechtelijke onderscheid tussen beide vertaalt zich immers lang niet altijd even zuiver in het vervolgings-, bestraffings- en ruimer strafrechtelijk beleid), geplaatst in de - zich steeds verder ontwikkelende - internationaalrechtelijke context.

Gezien de Wet van 2005 in essentie was bedoeld om de nationaalrechtelijke vertaalslag te vormen van $\mathrm{VN}$ - en EU-rechtsinstrumenten ter zake die in de jaren daarvoor waren tot stand gekomen, trapt deze bijdrage af met een overzicht van de internationaalrechtelijke evoluties in het ruimere domein van de mensenhandel en mensensmokkel. Sinds de Wet van 2005 is het internationale strafbaarstellingsbeleid evenwel alweer in volle evolutie. Navolgend internationaalrechtelijk overzicht reikt derhalve ook het referentiekader aan waaraan het Belgische materieel strafrecht inzake mensenhandel (zoals het er sinds de Wet van 2005 uitziet) - net zoals overigens het Nederlandse - binnenkort opnieuw zal moeten worden getoetst, onder meer gevolg aan een nieuwe EU-richtlijn mensenhandel.

Wat vervolgens het corpus van deze bijdrage betreft, inzake het Belgische materieel strafrecht, wordt een onderscheid gemaakt tussen de situatie voor de Wet van 2005 en de situatie sindsdien - het huidige recht. Tevens wordt vooruitgeblikt naar wetswijzigingen waartoe een omzetting van de nieuwe EU-richtlijn mensenhandel zal moeten of zou kunnen leiden.

3 Wet ro augustus 2005 tot wijziging van diverse bepalingen met het oog op de versterking van de strijd tegen mensenhandel en mensensmokkel en tegen praktijken van huisjesmelkers, B.S., 2 september 2005. Het eerste voorontwerp van deze wet dateert van juli 2004. De regering diende haar definitieve wetsontwerp in de Kamer in op I4 januari 2005. Na amendering door de Kamercommissie Justitie werd het wetsontwerp unaniem goedgekeurd in de plenaire vergadering van de Kamer op 2I april 2005, waarna de Senaat besliste het ontwerp te evoceren. Nadat het wetsontwerp opnieuw werd gewijzigd, werd het door de Commissie Justitie en in de plenaire vergadering van de Senaat aangenomen op respectievelijk Io mei en 2 juni 2005. Het gewijzigde wetsontwerp werd teruggestuurd naar de Kamer waar het uiteindelijk in onveranderde vorm werd aangenomen in de plenaire vergadering van 7 juli 2005 (Wetsontwerp tot wijziging van diverse bepalingen met het oog op de versterking van de strijd tegen mensenhandel en mensensmokkel, Parl.St. Kamer, 2004-2005, 5I-I56o/ooI-oI4; Parl. St. Senaat, 2004-2005, 3-II38/00I007). Voor een uitvoerige bespreking van de parlementaire werkzaamheden naar aanleiding van de wet van 2005, zie ook: CGKR, Rapport mensenhandel. Het Belgische mensenhandelbeleid: gewikt en gewogen, november 2005, I7-I9.

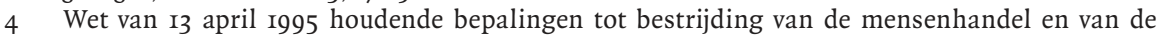
kinderpornografie, B.S. 25 april 1995. 
Navolgend - bij wijze van boni - is er resoluut voor gekozen het debat open te trekken naar twee vraagstukken die indirect zeer sterk de beleidsopties die in het materieel strafrecht inzake mensenhandel hun vertaling krijgen, beïnvloeden - in België zowel als in Nederland. Ten eerste worden de mogelijkheden verkend om de strijd tegen mensenhandel te versterken via maatregelen in de seksuele dienstenmarkt. Stelling daarbij is dat de legalisering (zoals in Nederland) of (zelf)regulering van nietuitbuitende vormen van exploitatie van geïnformeerd-consensuele seksuele dienstverlening nuttig kan bijdragen aan een hedendaags strafrechtelijk beleid inzake mensenhandel. Ten tweede wordt de strijd tegen mensenhandel gekoppeld aan het migratievraagstuk. Stelling daarbij is dat een opener (arbeids)migratiebeleid veel potentieel biedt om de kwetsbaarheid voor mensenhandel te verminderen.

De bijdrage wordt afgerond met een reeks concrete aanbevelingen.

\section{Internationaalrechtelijke context}

Algemeen wordt aangenomen dat mensenhandel en mensensmokkel per definitie grensoverschrijdend zijn. Vandaar ook dat niet alleen op nationaal, maar ook op globaal, internationaal en Europees niveau koortsachtig werd gezocht naar oplossingen, of althans manieren om beide criminaliteitsfenomenen op efficiënte(re) wijze te bestrijden. Zowel de Verenigde Naties (VN), de Raad van Europa (RvE), de Organisatie voor Veiligheid en Samenwerking in Europa (OVSE) als de Europese Unie EU) hebben, in het bijzonder in de afgelopen tien jaar, ruim aandacht besteed aan de problematiek van de mensenhandel en mensensmokkel, zoals blijkt uit de verscheidene rechtsinstrumenten, actieplannen, rapporten en andere beleidsteksten die in de schoot van de voormelde organisaties tot stand zijn gekomen en allen tot doel hebben bij te dragen tot de internationale strijd tegen mensenhandel en -smokkel. Sommige daarvan bevatten bindende richtlijnen voor de (lid)staten en zijn om die reden - nog meer dan de andere - van wezenlijk belang voor de (nationale) strijd tegen mensenhandel en -smokkel. Zo werden naar aanleiding van het Verdrag tegen transnationale, georganiseerde misdaad van I5 november 2000 door de Verenigde Naties twee aanvullende protocollen aangenomen die de ratificerende staten er onder meer toe verplichten maatregelen te treffen om de mensenhandel en -smokkel te voorkomen, bestrijden en bestraffen, de internationale samenwerking in dit verband te verbeteren en voor de slachtoffers in de nodige bijstand en 
bescherming te voorzien. ${ }^{5,6}$ Naar het voorbeeld van de Verenigde Naties nam ook de Europese Unie op I9 juli 2002 een Kaderbesluit aan inzake de bestrijding van mensenhandel.7 Later volgde nog het Kaderbesluit van 28 november 2002 tot versterking van het strafrechtelijk kader voor de bestrijding van de hulpverlening bij illegale binnenkomst, illegale doortocht en illegaal verblijf, dat verder werd uitgewerkt door de Richtlijn van de zelfde datum tot omschrijving van de hulpverlening bij illegale binnenkomst, illegale doortocht en illegaal verblijf. ${ }^{8}$ Beide kaderbesluiten zijn zonder meer bindend voor alle lidstaten van de Europese Unie en verplichten hen er onder meer toe mensenhandel en -smokkel strafbaar te stellen en met voldoende doeltreffende, evenredige en afschrikkende strafrechtelijke sancties, die uitlevering (intussen vervangen door: overlevering) voor deze misdrijven mogelijk maken, te bestraffen. Nog recenter, opnieuw op Europees niveau, kwam in de schoot van de Raad van Europa het Verdrag ter bestrijding van mensenhandel tot stand dat, eenmaal in werking, de ratificerende staten er eveneens toe zal verplichten het nodige te doen om de mensenhandel te voorkomen, bestrijden en bestraffen, de internationale samenwerking in dit verband te verbeteren en de slachtoffers bij te staan en te beschermen. ${ }^{9}$

De genoemde rechtsinstrumenten zijn om meerdere redenen van belang. Niet alleen wordt gepleit voor een integrale benadering van de problematiek van de mensenhandel en -smokkel (naast van repressie, dient ook werk gemaakt van preventie en van opvang, begeleiding en bescherming van de slachtoffers), bovendien geeft de internationale gemeenschap er ondubbelzinnig mee aan dat een onderscheid moet wor-

5 Voor zover zij deze protocollen ondertekend en nadien bekrachtigd, aanvaard of goedgekeurd hebben uiteraard. België deed dit en is bijgevolg gebonden door beide protocollen (Wet van 24 juni 2004 houdende instemming met de volgende internationale akten: (I) het Verdrag van de Verenigde Naties tegen transnationale georganiseerde misdaad; (2) het Aanvullend Protocol tegen de smokkel van migranten over land, over de zee en in de lucht, bij het Verdrag van de Verenigde Naties tegen transnationale georganiseerde misdaad; (3) het Aanvullend Protocol inzake de preventie, bestrijding en bestraffing van mensenhandel, in het bijzonder vrouwenhandel en kinderhandel, bij het Verdrag van de Verenigde Naties tegen transnationale georganiseerde misdaad, gedaan te New York op I5 november 2000; (4) het Aanvullend Protocol tegen de ongeoorloofde vervaardiging van en handel in vuurwapens, de onderdelen, componenten en munitie ervan, bij het Verdrag van de Verenigde Naties tegen transnationale georganiseerde misdaad, gedaan te New York op 3I mei 200I, B.S. I3 oktober 2004).

6 Protocol to prevent, suppress and punish trafficking in persons, especially women and children, supplementing the United Nations Convention against transnational, organized crime, I5 november 2000; Protocol against the smuggling of migrants by land, sea and air, supplementing the United Nations Convention against transnational organized crime, I5 november 2000.

7 Kaderbesluit 2002/629/JBZ van de Raad van I9 juli 2002 inzake bestrijding van mensenhandel, P.B. I augustus 2002, L 203/I.

8 Kaderbesluit van de Raad van 28 november 2002 tot versterking van het strafrechtelijk kader voor de bestrijding van hulpverlening bij illegale binnenkomst, illegale doortocht en illegaal verblijf, P.B. 5 december 2002, Nr. L 328/I; Richtlijn 2002/90/EG van de Raad van 28 november 2002 tot omschrijving van hulpverlening bij illegale binnenkomst, illegale doortocht en illegaal verblijf, P.B. 5 december 2002, L 328/17.

9 Council of Europe Convention on action against trafficking in human beings, CETS I97, Warschau, I6 mei 2005. 
den gemaakt tussen mensenhandel enerzijds en mensensmokkel anderzijds. ${ }^{\text {to }} \mathrm{Het}$ gaat om twee criminaliteitsfenomenen die weliswaar nauw verband kunnen houden met elkaar - en om die reden meer dan eens met elkaar verward worden - maar fundamenteel van elkaar verschillen. ${ }^{\text {II }}$ Mensenhandel en mensensmokkel hebben immers andere wezenskenmerken en ook de strafbaarstelling ervan heeft een andere finaliteit. Terwijl er voor mensensmokkel sprake moet te zijn van (illegale) grensoverschrijding en een winstoogmerk in hoofde van de smokkelaar, wordt mensenhandel getypeerd door het uitbuitingsaspect dat eraan vast zit en door het gebruik van geweld, dwang, misleiding, bedrog ten aanzien van het slachtoffer of het misbruik van diens kwetsbare positie. De strafbaarstelling van mensenhandel heeft tot doel personen te beschermen tegen gedwongen of onvrije exploitatie. De strafbaarstelling van mensensmokkel daarentegen heeft in eerste instantie tot doel het grondgebied of de eigen (nationale) economische of andere belangen te beschermen, en heeft weinig uitstaans met de bescherming van de menselijke waardigheid. Mensensmokkel moet dus veeleer als een misdrijf tegen de staat, dan als een misdrijf tegen de mens - zoals mensenhandel er één is - beschouwd worden. ${ }^{12}$ Vandaar dus de noodzaak en het belang om mensenhandel en mensensmokkel duidelijk van elkaar te onderscheiden, zoals dus blijkt uit het feit dat beide criminaliteitsfenomenen het voorwerp uitmaken van twee afzonderlijke VN-protocollen en EUKaderbesluiten.

Metde aannemingvan genoemde rechtsinstrumenten beklemtoont de internationale gemeenschap ook het belang van een duidelijke materieelstrafrechtelijke omschrijving van mensenhandel en -smokkel. Uit onderzoek kwam immers naar voor dat de strijd tegen mensenhandel voornamelijk wordt bemoeilijkt door een gebrek aan consensus omtrent hetgeen eronder moet worden begrepen, en de daarmee gepaard gaande conceptuele verwarring tussen mensenhandel, mensensmokkel en illegale migratie. ${ }^{13}$ Vandaar dat op internationaal en Europees niveau werk werd

Io Ook in het rapport van eind 2004 van de EU-Deskundigengroep mensenhandel die in 2003 door de Europese Commissie in het leven werd geroepen (Besluit van de Commissie van 25 maart 2003 tot oprichting van de adviesgroep 'Deskundigengroep mensenhandel', P.B., 26 maart 2003, $\mathrm{L}$ 79/25) en tot doel heeft bij te dragen tot de verdere ontwikkeling van de preventie en de bestrijding van de mensenhandel en de Europese Commissie adviezen te verstrekken met betrekking tot haar initiatieven op het gebied van mensenhandel, werd de (conceptuele) verwarring over het onderscheid tussen mensenhandel, mensensmokkel en illegale migratie als een van de belangrijkste problemen in het kader van de strijd tegen de mensenhandel aangehaald (Report of the experts group on trafficking in human beings, Brussel, 22 december 2004, 47).

II Mensenhandel wordt van oudsher heel sterk gelinkt aan de smokkel van migranten. De voornaamste oorzaak hiervan is gelegen in het feit dat mensenhandel en mensensmokkel vaak - niet altijd - samen voorkomen. Gesmokkelde personen die illegaal in het land verblijven en er tewerkgesteld worden als gevolg van hun illegale status, lopen doorgaans immers een groter risico om (in hun tewerkstelling) uitgebuit te worden en het slachtoffer te worden van mensenhandel.

I2 Zie: G. Vermeulen, 'Matroesjka's: tien jaar later. Repressie en controle als speerpunten van het vernieuwde mensenhandelbeleid?', Panopticon, 2005.2, 3-4; G. Warson, 'Mensenhandel: artikel 77bis VW.', Comm. Straf., 3.

I3 De afwezigheid van een consensus omtrent de definitie van mensenhandel werd ook door de EU-Deskundigengroep als een van de voornaamste problemen in de strijd tegen mensenhandel naar voor geschoven (rapport van de EU-Deskundigengroep van 22 december 2004, p. 47). 
gemaakt van een definitie van mensenhandel die algemeen werd aanvaard. Mensenhandel wordt er - zonder wezenlijke onderlinge verschillen tussen de diverse rechtsinstrumenten - gedefinieerd als de werving, het vervoer, de overbrenging, maar eventueel ook de huisvesting en de opneming, met inbegrip van de wisseling of de overdracht van de controle over een persoon door middel van geweld, dwang, bedreiging, ontvoering, misleiding, fraude, misbruik van een machtspositie of een situatie van kwetsbaarheid, betalingen of beloningen aan diegene die controle heeft over de verhandelde persoon, met de bedoeling de betrokkene uit te buiten in de seksuele of economische sfeer of - daarin niet gevolgd door het EU-Kaderbesluit - zijn organen/weefsels weg te nemen. ${ }^{\mathrm{I}}$ Volgens de VN- en EU-mensenhandeldefinities in kwestie moet er voor mensenhandel met andere woorden zowel een bewegingselement als een uitbuitingselement voorhanden zijn, en moet er tevens sprake zijn van dwang of onvrijheid, i.e. een gebrek aan vrije keuze, in hoofde van het slachtoffer. ${ }^{15}$ Pas dan kan men worden vervolgd en bestraft voor mensenhandel. Wat mensensmokkel betreft, moet volgens de internationale gemeenschap een onderscheid worden gemaakt tussen de smokkel van migranten enerzijds en de loutere hulp bij de illegale binnenkomst anderzijds. Volgens het VN-Mensensmokkelprotocol is er pas sprake van mensensmokkel wanneer men met de hulpverlening bij de illegale binnenkomst van een persoon, die geen onderdaan is van de staat waarin wordt binnengekomen en evenmin het recht heeft permanent op het grondgebied ervan te verblijven, de bedoeling heeft (on)rechtstreeks een vermogensvoordeel of een ander materieel voordeel te verwerven. ${ }^{16}$ Behalve een grensoverschrijding, veronderstelt mensensmokkel dus tevens dat uit winstbejag wordt gehandeld, zoals ook blijkt uit de EU-richtlijn van 28 november 2002 tot omschrijving van de hulpverlening bij illegale binnenkomst, illegale doortocht en illegaal verblijf.

Ruim voor twee jaar werd op EU-niveau beslist het met het Kaderbesluit van 2002 gecreëerde materieelstrafrechtelijk minimumkader inzake mensenhandel opnieuw bij te stellen. Daartoe werkte de Europese Commissie een voorstel van wijzigingskaderbesluit uit, waarover de onderhandelingen het bijna-eindstadium bereikten aan de vooravond van de inwerkingtreding van het Verdrag van Lissabon. Gevolg aan de institutionele wijzigingen die dat laatste introduceerden (onder meer medebeslissingsbevoegdheid van het Europees Parlement, stemming bij gekwalificeerde meerderheid en een aangepast rechtsinstrumentarium, inclusief voor de beleidsdomeinen van de voormalige derde pijler) diende alles over. In maart 2010 pikte de Europese Commissie de draad op en kwam met een voorstel van richtlijn. ${ }^{17}$ Op basis daarvan werd onderhandeld, en inmiddels heeft de Raad van ministers van justitie

I4 Artikel 3 VN-Mensenhandelprotocol en artikel I Kaderbesluit van de Raad van I9 juli 2002 inzake bestrijding van mensenhandel.

I5 Bovendien wordt aangenomen dat wanneer er sprake is van dwang of onvrijheid in hoofde van het slachtoffer, hij of zij niet kan instemmen met de voorgenomen of bestaande uitbuiting. A contrario kan hieruit worden afgeleid dat ingeval er geen sprake is van dwang of onvrijheid, het slachtoffer - voor zover dit meerderjarig is - volgens het VN-Mensenhandelprotocol en het EU-Kaderbesluit inzake mensenhandel wel kan instemmen met de voorgenomen of bestaande uitbuiting.

I6 Artikel 3 VN-Mensensmokkelprotocol.

I7 Zie: Raad van de Europese Unie, 8I57/Io. 


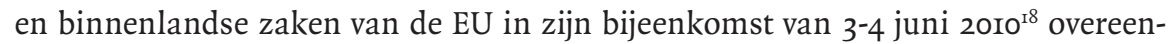
stemming bereikt over een algemene oriëntatie ('politiek akkoord') met betrekking tot de nieuwe richtlijn. ${ }^{\text {I9 }}$ Zodra deze formeel is aangenomen (waarna de lidstaten uiteraard de tijd krijgen om hun nationaal recht eraan te conformeren; wellicht 30 maanden), zal de richtlijn het kaderbesluit van 2002 vervangen. De toekomstige richtlijn brengt - wat aspecten van materieel strafrecht betreft - in essentie aanpassingen aan de bepalingen betreffende de vereiste minimumomschrijving van het misdrijf mensenhandel en de verplichting tot het vestigen van extraterritoriale rechtsmacht. Nieuw is ook dat de mogelijkheid moet worden gegarandeerd dat slachtoffers niet zouden worden vervolgd en bestraft voor misdrijven die ze in die hoedanigheid plegen. Ten slotte wordt gesuggereerd de bewuste gebruikmaking van diensten geleverd door een slachtoffer van mensenhandel strafbaar te stellen. De andere aspecten hebben betrekking op formeelstrafrechtelijke kwesties (te hanteren onderzoeksmethoden, een speciale behandeling van slachtoffers in strafprocedures enzovoort), een hogere norm voor bescherming van en bijstand aan slachtoffers (in het bijzonder speciale beschermingsmaatregelen voor kinderen) en preventieve maatregelen gericht op ontmoediging aan de vraagzijde.

Inzake kinderpornografie en seksuele uitbuiting van kinderen - domeinen waarop de uitbuiting van kinderhandel kan zijn gericht (en die materieelstrafrechtelijk dus ook van belang zijn voor de interpretatie van mensenhandel, ook al wordt er in deze bijdrage verder geen aandacht aan besteed) - is de evolutie geheel vergelijkbaar. Ook hier wordt het 'oude' kaderbesluit van 2004 binnenkort vervangen door een richtlijn. ${ }^{20}$ De timing loopt alleen iets achter in vergelijking met het mensenhandeldossier.

I8 Raad van de Europese Unie, 3018e Zitting van de Raad Justitie en Binnenlandse Zaken, Io630/I/Io REV I PRESSE I6I PR CO I, Luxemburg, 3-4 juni 20I0, 24.

I9 Voor de tekst, zie: Raad van de Europese Unie, Voorstel voor een richtlijn van het Europees Parlement en de Raad inzake de voorkoming en bestrijding van mensenhandel en de bescherming van slachtoffers en tot intrekking van Kaderbesluit 2002/629/JBZ, I0330/Io DROIPEN 56 MIGR 55 CODEC 49I, Brussel, 28 mei 2010.

20 Het Commissievoorstel dateert eveneens van 30 maart 20 Io (het aanvankelijk door de Commisie ingediende voorstel van wijzigingskaderbesluit raakte ook niet rond voor de inwerkingtreding van het Verdrag van Lissabon). Zie: Council of the European Union, Proposal for a Directive of the European Parliament and of the Council on combating the sexual abuse, sexual exploitation of children and child pornography, repealing Framework Decision 2004/68/JHA, 8I55/I0 DROIPEN 29 JAI 269, Brussel, 30 maart 20I0. Voor de stand van zaken, waarvan het voorzitterschap de ministers van justitie op de Raadsvergadering van 3-4 juni 20 ro heeft in kennis gesteld, zie: Council of the European Union, Presidency report on the proposal for a Directive of the European Parliament and of the Council on combating the sexual abuse, sexual exploitation of children and child pornography, repealing Framework Decision 2004/68/JHAIo335/r/Io REV I DROIPEN 57 JAI 493 CODEC 493, Brussel, 2 juni 20I0, 26-27. Zodra de richtlijn zal zijn aangenomen, zal deze het kaderbesluit van 2004 vervangen. De nog niet opgeloste vraagstukken zijn onder meer: de definitie van kinderpornografie, de kwalificatie van misdrijven, het aanzetten tot, de medeplichtigheid bij en het voorbereiden van dergelijke misdrijven, de strafbaarstelling van de opzettelijke toegang langs elektronische weg tot kinderpornografie, voorzieningen voor onopzettelijke toegang tot websites, de duur van de straffen, de uitbreiding van de territoriale rechtsmacht, het blokkeren van internetpagina's met kinderpornografie, als aanvullend middel bij de inspanningen om de inhoud aan de bron te verwijderen, het opnemen van fictieve personages (tekeningen, stripfiguren, enz.) in het concept van kinderpornografie (de Commissie heeft in dit verband gepreciseerd dat beoogd wordt beelden die de realiteit weergeven, strafbaar te stellen), en het beoordelen en aanbieden van rehabilitatieprogramma's voor plegers van dergelijke misdrijven. 


\title{
3 Belgisch materieel strafrecht
}

\section{I Voor de Wet van ro augustus 2005}

\subsubsection{Mensenhandel}

Oorspronkelijk was in het Strafwetboek geen bepaling voorzien aan de hand waarvan de mensenhandel strafrechtelijk kon worden gesanctioneerd. Daarin kwam pas verandering met de Wet van 26 mei I9I4 die in de Strafwet een artikel 38obis invoerde op grond waarvan de mensenhandel kon worden vervolgd en bestraft. ${ }^{21} \mathrm{Dit}$ artikel voorzag immers in de strafbaarstelling van

\begin{abstract}
'al wie, ten einde eens anders driften te voldoen, door bedrog of door geweld, bedreiging, misbruik van gezag of door welk ander dwangmiddel, een meerderjarige vrouw of een meerderjarig meisje tot het plegen van ontucht heeft verronseld, verleid of vervreemd'.
\end{abstract}

Aanvankelijk moest voor mensenhandel met andere woorden een element van dwang of onvrijheid in hoofde van het slachtoffer voorhanden zijn. Had de meerderjarige vrouw of het meerderjarige meisje daarentegen toegestemd, dan kon men overeenkomstig het toenmalige artikel 380 obis Sw. niet worden bestraft. In de jaren die volgden echter werd het toepassingsgebied van het toenmalige artikel 380 obis Sw. stelselmatig uitgebreid: zowel de handel in vrouwen, mannen als kinderen met het oog op het plegen van ontucht of prostitutie werd strafbaar gesteld, ongeacht de toestemming van het slachtoffer en zonder dat er gebruik moest zijn gemaakt van bedrog, geweld, bedreigingen, misbruik van gezag of andere dwangmiddelen. ${ }^{22}$

Ondanks de geleverde wetgevende inspanningen, kwam men begin jaren negentig, naar aanleiding van een parlementair onderzoek naar de vrouwenhandel en gedwongen prostitutie in België, niettemin tot de vaststelling dat de strafwetsbepalingen met betrekking tot de exploitatie van de prostitutie ontoereikend waren voor een succesvolle bestrijding van de mensenhandel. ${ }^{23}$ Volgens de parlementaire

2I Wet van 26 mei I9I4 tot bestrijding van de handel in vrouwen en meisjes, B.S. Io juni I9I4. Deze wet had tot doel de Belgische wetgeving in overeenstemming te brengen met het Internationaal Verdrag van 4 mei rgIo betreffende de handel in vrouwen en meisjes (B.S. 20 augustus I9I4).

22 Zie daarvoor: Wet van 25 mei 1936 tot goedkeuring van de Internationale Overeenkomst, gesloten te Genève op II oktober 1933, ter bestrijding van den handel in meerderjarige vrouwen, en tot aanvulling van artikel 38obis van het Strafwetboek, alsmede van artikel 2 van de Wet van 26 mei I9I4 tot bestrijding van den handel in vrouwen en meisjes, B.S. 29-30 juni 1936; Wet van 2I augustus 1948 tot afschaffing van de officiële reglementering van de prostitutie, B.S. I3-I4 september 1948 .

23 Vermeld parlementair onderzoek werd ingesteld nadat in 1992 een ophefmakend boek verscheen waarin door de auteur-journalist C. De Stoop uitvoerig werd ingegaan op de vrouwenhandel en gedwongen prostitutie die op dat ogenblik in België plaatsgreep. Het had tot doel, op grond van een diepgaand onderzoek van alle betrokken sectoren en de verschillende aspecten van het probleem, tot aanbevelingen te komen die een structureel beleid mogelijk zouden maken met het oog op de bestraffing en uitroeiing van de internationale vrouwenhandel (Voorstel tot oprich- 
onderzoekscommissie liet de strafrechtelijke aanpak van de mensenhandel te wensen over en moest dringend werk worden gemaakt van nieuwe strafrechtelijke bepalingen die Justitie in staat zouden stellen krachtdadig(er) op te treden tegen de mensenhandelaars en hun netwerken. ${ }^{24}$ Als reactie hierop nam de regering, op voorstel van de parlementaire onderzoekscommissie, vrijwel onmiddellijk de Wet van I3 april I995 aan die in een ruimere strafbaarstelling en tevens strengere bestraffing van de mensenhandel voorzag. ${ }^{25}$

Naar aanleiding van deze wet werd het toenmalige artikel 380 bis Sw. wederom herschreven. Volgens het aldus aangepaste artikel 380 bis, paragraaf $\mathrm{I}, \mathrm{I}^{\circ} \mathrm{Sw}$., dat intussen werd hernummerd in artikel 380 , paragraaf $\mathrm{I}, \mathrm{I}^{\circ} \mathrm{SW}$., is er sprake van mensenhandel zodra een persoon

'ten einde eens anders driften te voldoen, een meerderjarige zelfs met zijn toestemming, aanwerft, meeneemt, wegbrengt of bij zich houdt met het oog op het plegen van ontucht of prostitutie'. ${ }^{26}$

Voor de strafbaarheid van mensenhandel met het oog op seksuele exploitatie werd door het gewijzigde artikel opnieuw niet vereist dat door de dader tevens gebruik werd gemaakt van listige kunstgrepen, geweld, bedreigingen of enige andere vorm van dwang of dat hij misbruik heeft gemaakt van de bijzondere kwetsbare positie waarin een persoon om bepaalde redenen kan verkeren. ${ }^{27}$ Met andere woorden was de aanwezigheid van dwang of onvrijheid in hoofde van het slachtoffer geen constitutief bestanddeel van het misdrijf mensenhandel, doch enkel een verzwarende omstandigheid die leidt tot een strengere bestraffing van de mensenhandel. ${ }^{28}$ Arti-

ting van een Parlementaire onderzoekscommissie belast met het onderzoek naar een structureel beleid gericht tegen de internationale vrouwenhandel (Gedr. St,. Kamer I99I-92, nr. 673/I, I-4; Gedr. St,. Kamer, I99I-92, nr. 673/6, I-2).

24 Parlementair onderzoek naar een structureel beleid met het oog op de bestraffing en de uitroeiing van de mensenhandel. Verslag namens de onderzoekscommissie uitgebracht door mevr. Merckx-Van Goey en mevr. De T'Serclaes, Gedr. St., Kamer, I99I-92, nr. 673/7, I05 p.; B. De Ruyver, K. Van Heddeghem en N. Siron, 'De strijd tegen mensenhandel: een beleidsprioriteit in België. Stevige, niet-aflatende reactie na late ontdekking', Tijdschrift voor Criminologie, $2001,408$.

25 Wet van I3 april I995 houdende bepalingen tot bestrijding van de mensenhandel en van de kinderpornografie, B.S. 25 april 1995.

26 Artikel 380, par. I Sw. voorziet daarvoor in een gevangenisstraf van I tot 5 jaar en een geldboete van 500 tot 25.000 euro (te vermenigvuldigen met de wettelijke opdeciemen).

27 De toestemming van het slachtoffer doet niet ter zake, ongeacht of gebruik werd gemaakt van dwang of onvrijheid.

28 Artikel 380 , par. 3 Sw. voorziet daarvoor in een opsluiting van Io tot 15 jaar en een geldboete van 500 tot 50.000 euro (te vermenigvuldigen met de wettelijke opdeciemen). Een andere verzwarende omstandigheid die door de Wet van ${ }_{3} 3$ april 1995 werd ingevoerd, betreft het geval waarin de mensenhandel de hoofd- of bijkomende bedrijvigheid uitmaakt van een vereniging (artikel 38r Sw.).

De minderjarigheid van het slachtoffer is daarentegen geen verzwarende omstandigheid: de handel in kinderen jonger dan 16 jaar met het oog op hun seksuele exploitatie werd door de Wet van I3 april 1995 als een autonoom misdrijf strafbaar gesteld in artikel 380 , par. $4, \mathrm{I}^{\circ} \mathrm{Sw}$. dat daarvoor een opsluiting van Io tot 15 jaar en een geldboete van Iooo tot 100.000 euro (te vermenigvuldigen met de wettelijke opdeciemen) bepaalde. Bovendien voorzag de Wet van I3 april I995 in artikel 380, par. 5 Sw. een zwaardere straf voor het geval het kind geen ro jaar oud was. 
kel 380, paragraaf I, $\mathrm{I}^{\circ} \mathrm{Sw}$. wijkt hierin dus af van hetgeen momenteel op internationaal en Europees niveau over mensenhandel wordt gezegd: volgens de VN- en EU-mensenhandeldefinities en het rapport van de EU-deskundigengroep mensenhandel moet er voor mensenhandel immers niet alleen een bewegings- en uitbuitingselement, doch ook een element van dwang, onvrijheid of afwezigheid van vrije keuze en toestemming aanwezig zijn. ${ }^{29}$ Daarenboven heeft artikel 380, paragraaf I, $\mathrm{I}^{\circ} \mathrm{Sw}$. een beperkt toepassingsgebied: het viseert uitsluitend mensenhandel met het oog op seksuele exploitatie, en niet de situaties waarin arbeids- of dienstenexploitatie of het wegnemen van organen of weefsels tot doel wordt gesteld en die volgens de huidige $\mathrm{VN}$ - en EU mensenhandeldefinities nochtans ook bestraft moeten worden.

Behalve in artikel 380 Sw. werd mensenhandel door de Wet van I3 april 1995 voor het eerst ook strafbaar gesteld in het intussen gewijzigde artikel 77bis Vreemdelingenwet..$^{30}$ Mensenhandel werd er omschreven als de situatie waarin een persoon

'op welke manier ook ertoe bijdraagt, rechtstreeks of via een tussenpersoon, dat een vreemdeling het Koninkrijk binnenkomt, er via doorreist of er verblijft, wanneer hij daarbij ten opzichte van de vreemdeling direct of indirect gebruik maakt van listige kunstgrepen, geweld, bedreigingen of enige andere vorm van dwang, of misbruik maakt van de bijzonder kwetsbare positie waarin de vreemdeling verkeert ten gevolge van een onwettige of precaire administratieve toestand, of van zijn staat van minderjarigheid of ten gevolge van zwangerschap, ziekte dan wel een lichamelijk of geestelijk gebrek of onvolwaardigheid'. ${ }^{\text {1, }}{ }^{32}$

Door de Wet van 28 november 2000 werd het toepassingsgebied van artikel 380 , par. 4 , I ${ }^{\circ}$ Sw. uitgebreid tot alle kinderen, inclusief diegene die tussen 16 en I 8 jaar oud zijn en werd de zwaardere straf uit artikel 380 , par. 5 van toepassing verklaard op alle gevallen waarin het slachtoffer van de mensenhandel geen 16 jaar is. Ook het feit dat de mensenhandelactiviteit een gewoonte uitmaakte, maakt volgens de Strafwet geen verzwarende omstandigheid uit.

29 HetVN-Mensenhandelprotocol en hetEU-Kaderbesluit inzake mensenhandel schuiven de dwang of onvrijheid als materieel element of wezenskenmerk van het misdrijf mensenhandel naar voor. Alleen wanneer sprake is van dwang of onvrijheid is de toestemming van het slachtoffer irrelevant, zo luidt het. Volgens artikel 380, par. 3 Sw. daarentegen maakt de dwang of onvrijheid een verzwarende omstandigheid en wordt mensenhandel in dat geval strafbaar gesteld met een opsluiting van Io tot 15 jaar en een geldboete van 500 tot 50.000 euro (te vermenigvuldigen met de wettelijke opdeciemen). In tegenstelling tot hetgeen in het VN-Mensenhandelprotocol en het EU-Kaderbesluit inzake mensenhandel wordt bepaald, is de toestemming van het slachtoffer volgens artikel 380 , par. I, I ${ }^{\circ}$ Sw. in elk geval irrelevant, zelfs wanneer ten aanzien van het slachtoffer geen gebruik werd gemaakt van dwang of geen misbruik werd gemaakt van de kwetsbare positie waarin hij om bepaalde redenen verkeert.

30 Wet van 15 december 1980 betreffende de toegang tot het grondgebied, het verblijf, de vestiging en de verwijdering van vreemdelingen, B.S. 3I december I980.

3I Artikel 77bis Vreemdelingenwet voorzag daarvoor in een gevangenisstraf van i tot 5 jaar en een geldboete van 500 tot 25.000 euro. Er waren strengere straffen bepaald voor het geval dat van de mensenhandelactiviteit een gewoonte werd gemaakt of wanneer zij de hoofd- of bijkomende bedrijvigheid uitmaakten van een vereniging.

32 In dit verband dient opgemerkt dat de gevallen van mensenhandel, waarbij het slachtoffer uitsluitend op doorreis is via ons land en (samen met zijn handelaar) wordt aangetroffen in de transitzone van de luchthaven in Zaventem, pas expliciet strafbaar gesteld met de Wet van 28 november 2000 betreffende de strafrechtelijke bescherming van minderjarigen (B.S. I7 maart 
In tegenstelling tot artikel 380 Sw. vereiste artikel 77 bis Vreemdelingenwet wel dat er dwang werd gebruikt of misbruik werd gemaakt van de kwetsbare positie van een vreemdeling, opdat er sprake zou zijn van mensenhandel: beide werden als wezenselementen van het misdrijf mensenhandel beschouwd. ${ }^{33}$ Voor de strafbaarstelling van mensenhandel werd verder geen belang gehecht aan de aard van de beoogde exploitatie: aan de hand van artikel 77 bis Vreemdelingenwet kon zowel de mensenhandel met het oog op seksuele of economische exploitatie worden bestraft. Met andere woorden werd de mensenhandel losgekoppeld van het exclusieve domein van de seksuele uitbuiting. Toch had ook artikel 77bis Vreemdelingenwet een beperkt toepassingsgebied in die zin dat het uitsluitend van toepassing was op vreemdelingen en alleen zij het slachtoffer konden worden van het erin voorziene mensenhandelmisdrijf. 34

Naast de ruimere strafbaarstelling van mensenhandel werd door de Wet van I3 april I995 tevens in een strengere bestraffing van de mensenhandel voorzien. Zo werden de straffen voor de mensenhandel, die in de Strafwet werden bepaald, verzwaard, werd ook de poging tot mensenhandel strafbaar gesteld en werd het arsenaal aan bijkomende straffen voor de strafrechter uitgebreid. ${ }^{35}$

Niettegenstaande de strafbaarstelling van mensenhandel met de Wet van I3 april 1995 werd verruimd, bleken artikel 380 Sw. en het nieuw ingevoerde artikel 77 bis Vreemdelingenwet ook na deze wet een zeer beperkt toepassingsgebied te hebben. Terwijl met artikel 380 Sw. uitsluitend de mensenhandel met het oog op seksuele exploitatie werd geviseerd, kon het voormalige artikel 77 bis Vreemdelingenwet enkel worden aangewend ter bestraffing van de handel in vreemdelingen. Gelet op de nadien tot stand gekomen internationale en Europese rechtsinstrumenten ter bestrijding van de mensenhandel, volgens dewelke ook de mensenhandel met het oog op de arbeids- en dienstenexploitatie of orgaanverwijdering strafbaar moet worden gesteld, werd het beperkte toepassingsgebied van artikel 380 bis Sw. en

200I) die aan de omschrijving in artikel 77bis Vreemdelingenwet de woorden 'er via doorreist' toevoegde.

33 Vandaar dat - hoewel niet uitdrukkelijk bepaald - de eventuele instemming van de vreemdeling ook door het voormalige artikel 77 bis Vreemdelingenwet niet relevant werd geacht voor de bestraffing van de mensenhandel (CGKR, Beeldvorming van de mensenhandel en analyse van de rechtspraak, mei 200I, 38).

34 Dit volgt uit het feit dat de bepaling werd opgenomen in de Wet van 15 december I980 betreffende de toegang tot het grondgebied, het verblijf, de vestiging en de verwijdering van vreemdelingen, dat - zoals de titel van de wet zelf zegt - uitsluitend van toepassing is op vreemdelingen.

35 Zoals reeds vermeld wordt de mensenhandel in artikel 380, par. I Sw. strafbaar gesteld met een gevangenisstraf van I tot 5 jaar en een geldboete van 500 tot 25.000 euro (te vermenigvuldigen met de wettelijke opdeciemen). Overeenkomstig artikel 380, par. 3 Sw. moet de poging daartoe bestraft worden met een gevangenisstraf van 6 maanden tot 3 jaar en een geldboete van roo tot 5000 euro (te vermenigvuldigen met de wettelijke opdeciemen). Wat de bijkomende straffen betreft, werd voor de strafrechter in de mogelijkheid voorzien om de sluiting te bevelen van de inrichting waar de mensenhandel werd gepleegd (artikel 382, 2e lid Sw., intussen hernummerd in artikel 382, par. 3 Sw.), en werden de mogelijkheden tot bijzondere verbeurdverklaring uitgebreid tot de zaken die verband houden met de mensenhandel, doch geen eigendom zijn van de veroordeelde mensenhandelaar (artikel 382 bis Sw., intussen hernummerd in artikel 382ter Sw.). 
artikel 77bis Vreemdelingenwet na verloop van tijd - geheel terecht - als een van de belangrijkste lacunes van de Belgische mensenhandelwetgeving beschouwd. Mede daarom werd beslist om de Belgische mensenhandelwetgeving grondig te herzien, hetgeen gebeurde met de Wet van Io augustus 2005. $\cdot^{36}$

\subsubsection{Mensensmokkel}

Voor de Wet van io augustus 2005 werd voor de bestraffing van de mensensmokkel steevast een beroep gedaan op het toenmalige artikel 77 Vreemdelingenwet. Dit artikel voorzag immers in de strafbaarstelling van diegene die

'wetens en willens een vreemdeling helpt of bijstaat, hetzij in de handelingen die zijn onwettig binnenkomen of zijn onwettig verblijf in het Rijk voorbereid hebben of ze vergemakkelijkt hebben, hetzij in de feiten die ze voltooid hebben; of wetens en willens een vreemdeling helpt of poogt te helpen het grondgebied van een Staat die partij is bij een internationale overeenkomst betreffende de overschrijding van de buitengrenzen, die België bindt, binnen te komen of aldaar te verblijven, zulks in strijd met de wetgeving van deze Staat betreffende de binnenkomst en het verblijf van vreemdelingen'. ${ }^{37}$

Werd de hulp of bijstand aan de vreemdeling echter voornamelijk om humanitaire redenen verstrekt, dan kon men volgens het toenmalige artikel 77 Vreemdelingenwet niet worden bestraft..$^{8}$ In tegenstelling tot hetgeen op internationaal en Europees niveau met betrekking tot mensensmokkel wordt bepaald, met name dat daarvoor uit winstbejag moet zijn gehandeld, werd voor een veroordeling op grond van artikel 77 Vreemdelingenwet niet vereist dat men met de hulp bij de illegale binnenkomst of het illegaal verblijf een vermogensvoordeel of ander materieel voordeel nastreefde of verwierf. Met andere woorden werd door de Belgische wetgever in artikel 77 Vreemdelingenwet geen onderscheid gemaakt tussen de loutere hulp bij de illegale binnenkomst of het illegaal verblijf, en de mensensmokkel, zoals op internationaal en Europees niveau wordt bepleit. Vandaar dat met de Wet van Io augustus 2005 ook de wetgevende bepalingen inzake mensensmokkel grondig dienden herzien.

36 Zo wordt in de memorie van toelichting bij de Wet van Io augustus 2005 uitdrukkelijk bepaald dat de nieuwe wetgeving er in eerste instantie toe strekt de bestaande wetgeving inzake mensenhandel en mensensmokkel in overeenstemming te brengen met de internationale en Europese rechtsinstrumenten die in het kader van de internationale strijd tegen de mensenhandel en -smokkel tot stand zijn gekomen en bindend zijn voor België (memorie van toelichting bij het Wetsontwerp van I4 januari 2005 tot wijziging van diverse bepalingen met het oog op de versterking van de strijd tegen mensenhandel en mensensmokkel, Parl. St. Kamer, 2004-2005, 5I-I560/00I, 3).

37 Artikel 77 Vreemdelingenwet voorzag daarvoor in een gevangenisstraf van 8 dagen tot 3 maanden en/of een geldboete van I.700 tot 6.000 euro (te vermenigvuldigen met de wettelijke opdeciemen). Ingeval van herhaling binnen een termijn van 3 jaar werd in een strengere straf voorzien: in dat geval kon een gevangenisstraf van één maand tot één jaar en/of een geldboete van 6.000 tot 30.000 euro worden uitgesproken.

38 Deze strafuitsluitende verschoningsgrond werd ingevoerd door de Wet van 29 april 1999 tot wij-

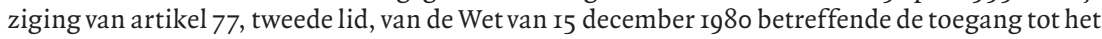
grondgebied, het verblijf de vestiging en de verwijdering van vreemdelingen, B.S. 26 juni I999. 


\subsubsection{Onderscheid mensenhandel en mensensmokkel}

Zoals hiervoor uiteengezet, werd voor de Wet van ro augustus 2005 voor de bestraffing van mensensmokkel een beroep gedaan op het toenmalige artikel 77 van de Vreemdelingenwet, en werd daarin met de Wet van I3 april I995 een artikel 77bis ingevoegd dat mensenhandel strafbaar stelde. Eigenlijk had die laatste strafbaarstelling evenwel betrekking op mensensmokkel voor zover dit gepaard ging met het dwang- of onvrijheidselement waarvan we het er vandaag over eens zijn dat het mensenhandel typeert. Voor de Wet van 2005 bleek het onderscheid tussen mensenhandel en -smokkel met andere woorden onvoldoende duidelijk uit de wet, hetgeen de verwarring tussen beide fenomenen op het terrein zonder twijfel in de hand gewerkt heeft - zeker op het niveau van de eerstelijnsdiensten.

\subsubsection{Rechtsmacht 39}

De Wet van I3 april 1995 voegde tevens een artikel roter in de Voorafgaande Titel van het Wetboek van Strafvordering (V.T. Sv.) in, waarmee België zich universeel bevoegd verklaarde voor onder meer extraterritoriale mensenhandel. Sinds de Wet van 28 november betreffende de strafrechtelijke bescherming van minderjarigen, $4^{\circ}$ waarbij artikel Ioter V.T. Sv. al voor de tweede keer werd gewijzigd (onder meer werd 'De Belg en de vreemdeling gevonden in België' vervangen door 'Eenieder'), en tot aan de mensenhandelwet van Io augustus 2005, waarbij het opnieuw werd aangevuld (infra), luidde het als volgt:

'Eenieder kan in België vervolgd worden wanneer hij zich buiten het grondgebied van het rijk schuldig maakt aan:

$\mathrm{I}^{\circ}$ een van de misdrijven voorzien in de artikelen $379,380,38 \mathrm{I}$ en $383 \mathrm{bis}$, paragraaf $\mathrm{I}$ en 3 van het Strafwetboek;

$2^{\circ}$ een van de misdrijven bepaald in de artikelen 372-377 en 409 van hetzelfde Wetboek, indien het feit werd gepleegd op een minderjarige;

$3^{\circ}$ een van de misdrijven bepaald in artikel 77bis, paragraaf 2 en 3 van de Wet van I5 december 1980 betreffende de toegang tot het grondgebied, het verblijf, de vestiging en de verwijdering van vreemdelingen en in de artikelen IO, II, I2 en I3 van de Wet van 9 maart 1993 ertoe strekkende de exploitatie van huwelijksbureaus te regelen en te controleren.'

39 Zie: G. Vermeulen, 'Strafrechtelijke bescherming van minderjarigen en verhoogde internationale bescherming van kinderen tegen seksuele exploitatie', in Jongeren en criminaliteit, T. Balthazar, J. Christiaens, M. Cools, T. Decorte, B. De Ruyver, P. Hebberecht, P. Ponsaers, S. Snacken, P. Traest, T. Vander Beken, G. Vermeulen (ed.), Mechelen, 2003, Gandaius/Kluwer, I93-225; G. Vermeulen, 'Kinderhandel, seksuele uitbuiting van kinderen, kinderporno en kindersekstoerisme. Naar een verdere internationale harmonisering van strafbepalingen en jurisdictierecht?', Panopticon, 2000, 200-207. Uitgebreider, zie: S. Bollaert, C. Georges en S. Voet, 'Extra-territoriale toepassing van de strafwet inzake misdrijven', in G. Vermeulen, Strafrechtelijke bescherming van minderjarigen, Antwerpen, Maklu, 200I, 488-532. 
Mensenhandel en mensensmokkel (toentertijd nog problematisch materieelstrafrechtelijk door elkaar vloeiend) konden op grond van punt $I^{\circ}$ van artikel roter V.T. Sv., verwijzend naar artikel $380 \mathrm{Sw}$. (exploitatie van prostitutie), respectievelijk punt $3^{\circ}$ ervan, verwijzend naar de Vreemdelingenwet en de wetgeving inzake huwelijksbureaus (die mogelijk als vehikel voor mensenhandel fungeerden), extraterritoriaal worden aangepakt.

De extraterritoriale bevoegdheid die België uit artikel roter V.T. Sv. put, is overigens zo goed als onvoorwaardelijk: nergens wordt verwezen naar een voorafgaande klacht, een officiële kennisgeving of dubbele incriminatie. De gemeenrechtelijke voorwaarde voor extraterritoriale rechtsmacht van een voorafgaande klacht of officiële berichtgeving werd reeds ter zijde gelaten door de initiële wet van I3 april I995. De vereiste van dubbele incriminatie, die de wet van I3 april 1995 wel nog stelde, werd met de Wet van 28 november 2000 geschrapt. Dat impliceert dat een buitenlander die in zijn thuisland een handeling stelt die daar niet strafbaar is, maar volgens de in artikel roter V.T. Sv. opgesomde misdrijven in België wel strafbaar is, in België kan worden vervolgd. Door het weglaten van de voorwaarde van dubbele incriminatie is artikel Ioter V.T. Sv. een bijzonder verregaande bepaling geworden. Het geeft België immers de mogelijkheid zijn strafrechtelijke normen inzake de opgesomde misdrijven (waaronder mensenhandel en mensensmokkel) op te dringen aan om het even welk ander land, ook al werden de door artikel Ioter V.T. Sv. geviseerde gedragingen er niet strafbaar gesteld. In Unieverband is dat vandaag niet meer zo'n probleem (gevolg aan de verplichting tot strafbaarstelling voortvloeiend uit de eerder genoemde kaderbesluiten van 2002 en 2004). De vraag rijst evenwel of de wetgever hier niet heel vroeg heel ver is gegaan ten aanzien van de rest van de wereld.

Voor de toepassing van artikel roter V.T. Sv. is voorts wel vereist dat de dader, zowel de Belg als de vreemdeling, op Belgisch grondgebied wordt gevonden. ${ }^{4 \mathrm{I}}$ Op die manier wordt de bevoegdheid van de Belgische rechter beperkt tot daders die in België worden aangetroffen (zonder dat om hun uitlevering kan worden gevraagd). Het stellen van de voorwaarde dat verdachten in België moeten worden aangetroffen is o.i. een goede zaak. Volkomen ongebreidelde universele jurisdictie is immers helemaal uit den boze. Overigens verdient nog te worden opgemerkt dat de wetgever oorspronkelijk, bij het tot stand komen van de wet van 28 november 2000, met de nieuwe formulering ('Eenieder') de bedoeling had ook voor de vreemdeling de voorwaarde in verband met het-moeten-gevonden-worden-in-België (zoals die gemeenrechtelijk is vastgelegd in artikel I2 V.T. Sv.) op te heffen, zoals dat voor de Belg reeds met de wet van I3 april 1995 was gebeurd. ${ }^{42}$ Na de Wet van I3 april 1995 en

4I In verband met het belang vast te houden aan de vereiste dat de Belgische of buitenlandse dader in België worden gevonden, zeker voor wat de niet Belgische verdachten betreft: zie onder meer G. Vermeulen, 'Justitie over de grens. Over noodzaak en mogelijkheid van een synthese tussen de belangen van strafrechtshandhaving en buitenlandse politiek bij vermoede ernstige schendingen van het internationaal humanitair recht', De Orde van de Dag, 2002.

42 Uit de verwoording in die aanvankelijke wet - 'De Belg of de vreemdeling gevonden in België' volgde a contrario dat de vereiste in België gevonden te worden niet gold voor Belgen, om wiens 
voor de wijzigingen die werden ingevoerd door de Wet van 28 november betreffende de strafrechtelijke bescherming van minderjarigen, kon een Belg die zich schuldig had gemaakt aan een van de misdrijven bedoeld in artikel roter V.T. Sv. in België worden vervolgd ongeacht of hij al dan niet in België werd aangetroffen. Sinds de Wet van 28 november 2000 gold - en geldt - opnieuw voor beide categorieën, zowel Belgen als vreemdelingen, dat zij in België moeten worden aangetroffen opdat zij op basis van artikel ıoter Sv. kunnen worden vervolgd. Tegelijk was de wetgever zinnens artikel ıoter V.T. Sv. in artikel I2 V.T. Sv. te vermelden als een artikel dat buiten de toepassingssfeer van artikel I2 V.T. Sv. viel. Uiteindelijk is de wetgever zijn oorspronkelijke intenties uit het oog verloren, zodat hij volkomen onbedoeld ook voor Belgen opnieuw de voorwaarde creëerde dat dezen in België moesten - en moeten worden gevonden. Op zich is dit-zij het kennelijk toevallig - een goede zaak. Op die manier blijft er minstens enige logische connectie met het grondgebied.

\subsection{Na de Wet van ro augustus 2005}

\subsubsection{Nieuwe strafbaarstelling mensenhandel}

De Wet van ro augustus 2005 tot wijziging van diverse bepalingen met het oog op de versterking van de strijd tegen mensenhandel en mensensmokkel en tegen praktijken van huisjesmelkers heeft de wettelijke bepalingen inzake mensenhandel grondig gewijzigd. ${ }^{43}$ Zo werd ervoor gekozen om de strafbaarstelling van mensenhandel - deze keer expliciet - in te schrijven in het Strafwetboek alleen. Voortaan wordt mensenhandel dus niet langer strafbaar gesteld in de Vreemdelingenwet. Bijgevolg kunnen dus zowel vreemdelingen als Belgen het slachtoffer worden van mensenhandel: mensenhandel hoeft niet langer grensoverschrijdend te zijn zoals het vroegere artikel 77 bis Vreemdelingenwet vereiste, ook de interne mensenhandel wordt strafbaar gesteld. ${ }^{44}$

Het misdrijf mensenhandel is, als autonoom misdrijf, opgenomen in de artikelen 433quinquies tot 433 nonies en wordt - voor het eerst ${ }^{45}$ - expliciet gedefinieerd als

uitlevering derhalve kon worden gevraagd in geval ze extraterritoriaal de feiten als bedoeld zouden plegen.

43 Wet van ro augustus 2005 tot wijziging van diverse bepalingen met het oog op de versterking van de strijd tegen mensenhandel en mensensmokkel en tegen praktijken van huisjesmelkers, B.S. 2 september 2005. Voor een juridische analyse van de wet van 2005, zie ook: CGKR, Rapport mensenhandel. Het Belgische mensenhandelbeleid: gewikt en gewogen, november 2005, 5-32.

44 Voor wat de strafbaarstelling op zich betreft, maakt de mensenhandelwet van 2005, in tegenstelling tot de internationale rechtsinstrumenten, geen onderscheid tussen mensenhandel en kinderhandel. Het feit dat het slachtoffer van de mensenhandel minderjarig is, is wel een verzwarende omstandigheid die overeenkomstig artikel 433 septies Sw. leidt tot een zwaardere bestraffing van de mensenhandel (memorie van toelichting bij het Wetsontwerp van I4 januari 2005 tot wijziging van diverse bepalingen met het oog op de versterking van de strijd tegen mensenhandel en mensensmokkel, Parl. St. Kamer, 2004-2005, 5I-I560/00I, p. 20).

45 Voorheen werd de term 'mensenhandel' niet uitdrukkelijk vermeld, noch in artikel 380 Sw. noch in het voormalige artikel77bis Vreemdelingenwet. 
'de werving, het vervoer, de overbrenging, de huisvesting, de opvang van een persoon, de wisseling of de overdracht van de controle over hem teneinde:

$I^{\circ}$ ten aanzien van deze persoon de misdrijven te laten plegen die bedoeld worden in de artikelen 379 , 380, paragraaf I en 4 , en 383 bis, paragraaf I;

$2^{\circ}$ ten aanzien van deze persoon het misdrijf te laten plegen dat bedoeld wordt in artikel 433 ter;

$3^{\circ}$ deze persoon aan het werk te zetten of te laten aan het werk zetten in omstandigheden die in strijd zijn met de menselijke waardigheid;

$4^{\circ}$ bij deze persoon organen of weefsels weg te nemen of te laten wegnemen in strijd met de Wet van 13 juni 1986 betreffende het wegnemen en transplanteren van organen; $5^{\circ}$ of deze persoon tegen zijn wil een misdaad of een wanbedrijf te doen plegen'. ${ }^{4}$

Bovendien werd opnieuw bepaald dat, met uitzondering van het in artikel 433quinquies, paragraaf $\mathrm{I}, 5^{\circ}$ bedoelde geval, de toestemming van het slachtoffer met de voorgenomen of daadwerkelijk uitbuiting van geen belang is.

Nieuw aan deze wetsbepaling was dat voortaan niet enkel mensenhandel met het oog op seksuele exploitatie strafbaar is, doch ook de mensenhandel met het oog op arbeidsexploitatie en de orgaan- of weefseldiefstal en -transplantatie, ongeacht of een Belg of vreemdeling daarvan het slachtoffer is. Daarmee werd tegemoet gekomen aan hetgeen internationaal en Europees wordt vereist, en werd komaf gemaakt met de belangrijkste tekortkoming van de voormalige mensenhandelwetgeving.

a Mensenhandel met het oog op seksuele exploitatie

- Het nieuw ingevoegde artikel 433quinquies, paragraaf $\mathrm{I}, \mathrm{I}^{\circ} \mathrm{SW}$. in samenspel met het bestaande artikel $380 \mathrm{Sw}$.

Artikel 433quinquies Sw. stelt in eerste instantie de mensenhandel strafbaar die erop gericht is

'ten aanzien van deze persoon de misdrijven te laten plegen die bedoeld worden in de artikelen 379, 380, paragraaf I en 4 en 383 bis, paragraaf I'.

Met deze artikelen wordt de mensen- en kinderhandel met het oog op seksuele exploitatie en kinderpornografie bedoeld. In tegenstelling tot hetgeen men - redelijkerwijze - had mogen verwachten, vervangen de nieuw ingevoegde strafwetsbepalingen inzake mensenhandel de ter zake reeds bestaande artikelen 379, 380, paragraaf $\mathrm{I}, \mathrm{I}^{\circ}, 2,3$ en $4, \mathrm{I}^{\circ} \mathrm{Sw}$. dus niet. Uit de memorie van toelichting bij de wet van 2005 blijkt dat de artikelen 379, 380, paragraaf I, I ${ }^{\circ}, 2,3$ en 4, I Sw. de men-

46 Artikel 433quinquies, par. 2 Sw. voorziet daarvoor in een gevangenisstraf van $\mathrm{I}$ tot 5 jaar en een geldboete van 500 tot 50.000 euro (te vermenigvuldigen met de wettelijke opdeciemen). 
sen- en kinderhandel met het oog op de exploitatie van ontucht of prostitutie blijven strafbaar stellen, en dus naast de artikelen 433quinquies tot nonies Sw. verder bestaan.

De memorie verantwoordt dit door te stellen dat een onderscheid moet worden gemaakt tussen de situatie waarin een persoon zich schuldig maakt aan mensenhandel teneinde zelf de betrokkene seksueel uit te buiten (hetgeen strafbaar blijft overeenkomstig artikel 380, paragraaf $\mathrm{I}, \mathrm{I}^{\circ} \mathrm{SW}$.) en de situatie waarin een persoon zich overeenkomstig artikel 433quinquies, paragraaf $\mathrm{I}, \mathrm{I}^{\circ}$ Sw. schuldig makt aan mensenhandel teneinde een ander, die zich dan tevens schuldig maakt aan mensenhandel, toe te laten de betrokkene seksueel uit te buiten. ${ }^{47}$ Met andere woorden is voortaan en vreemd genoeg voorzien in de strafbaarstelling van mensenhandel met het oog op mensenhandel in de seksuele sfeer. Daarvan zou bijvoorbeeld sprake kunnen zijn wanneer mensenhandel in de zin van artikel 433quinquies Sw. tot doel heeft een persoon in de prostitutie te laten exploiteren in de zin van artikel $380 \mathrm{Sw}$., dat op zich ook als mensenhandel moet worden beschouwd. Hoe het ook zij, vast staat dat dit een duidelijk begrip van hetgeen onder mensenhandel en als dusdanig strafbaar moet worden gesteld, in de weg staat. Om verwarring omtrent de strafbaarstelling van mensenhandel te vermijden, had men er dan ook beter aan gedaan de artikelen 379,380 , paragraaf $\mathrm{I}, \mathrm{I}^{\circ}, 2,3$ en $4, \mathrm{I}^{\circ} \mathrm{Sw}$. te integreren in de nieuwe strafwetsbepalingen inzake mensenhandel.

Verder dient nog opgemerkt dat de Belgische definitie, voor wat mensenhandel met het oog op seksuele exploitatie betreft, afwijkt van de internationale en Europese mensenhandeldefinities: met seksuele exploitatie wordt in artikel 433quinquies Sw. immers uitsluitend de exploitatie van de ontucht of prostitutie (artikelen 379 en 380, paragraaf I en 4 Sw.) en kinderpornografie (artikel 383 bis, paragraaf I Sw.) bedoeld, terwijl de internationale en Europese definities, en de EU-Deskundigengroep mensenhandel aan de seksuele exploitatie een ruimere invulling geven, en daarmee onder meer ook op de exploitatie in de volwassenenpornografie doelen. ${ }^{48}$

b Mensenhandel met het oog op economische exploitatie

- Volgens het voormalige artikel 77bis van de Vreemdelingenwet: misbruik van de kwetsbare positie van de vreemdeling

Vóór de Wet van Io augustus 2005 kon mensenhandel met het oog op economische uitbuiting, dat strafbaar was gesteld in het toenmalige artikel 77 bis Vreemdelingenwet, enkel bestraft worden voor zover een vreemdeling daarvan het slachtoffer was. De mensenhandel van nationale onderdanen met het oog op hun economische

47 Memorie van toelichting bij het Wetsontwerp van I4 januari 2005 tot wijziging van diverse bepalingen met het oog op de versterking van de strijd tegen mensenhandel en mensensmokkel, Parl. St. Kamer, 2004-2005, 5I-I560/00I, I8-I9.

48 Zie ook: CGKR, Rapport mensenhandel. Het Belgische mensenhandelbeleid: gewikt en gewogen, november 2005, 26. 
uitbuiting was op dat ogenblik (nog) niet strafbaar. Voor de bestraffing werd evenwel vereist dat 'ten opzichte van de vreemdeling direct of indirect gebruik was gemaakt van listige kunstgrepen, geweld, bedreigingen of enige ander vorm van dwang' of 'dat misbruik was gemaakt van de bijzonder kwetsbare positie waarin de vreemdeling verkeerde ten gevolge van zijn onwettige of precaire administratieve toestand'.

Vooral van dit laatste, dat misbruik was gemaakt van de kwetsbare positie van de vreemdeling en er bijgevolg sprake was van economische uitbuiting, konden de rechters ten gronde soms maar moeilijk overtuigd worden, hetgeen leidde tot een vrijspraak wegens de tenlasteleggingen op grond van artikel 77 bis van de Vreemdelingenwet. De vaststelling dat inbreuk werd gemaakt op de sociale wetgeving volstond en volstaat nog steeds niet om tot economische uitbuiting en bijgevolg mensenhandel te besluiten..$^{49}$ Met de nieuwe mensenhandelwet wilde men aan deze bewijsproblemen, die grotendeels het gevolg waren van de uiteenlopende interpretaties die aan de notie 'misbruik van de kwetsbare positie' werden gegeven, een einde maken.

- Volgens het nieuwe ingevoegde artikel 433quinquies, paragraaf I, $3^{\circ}$ Sw.: arbeidsomstandigheden in strijd met de menselijke waardigheid

Met de Wet van Io augustus 2005 werd de mensenhandel met het oog op arbeids- of dienstenexploitatie voor het eerst expliciet strafbaar gesteld in het Strafwetboek. Voortaan wordt erkend dat behalve vreemdelingen ook Belgen het slachtoffer kunnen worden van mensenhandel met het oog op economische uitbuiting.

Volgens artikel $433 q u i n q u i e s$, paragraaf $\mathrm{I}, 3^{\circ} \mathrm{Sw}$. is er sprake van economische uitbuiting wanneer men 'een persoon aan het werk zet of laat zetten in omstandigheden die in strijd zijn met de menselijke waardigheid'. Dwang of misbruik van de kwetsbare positie van de betrokkene is daarvoor niet langer vereist. ${ }^{50}$ Hiermee wordt opnieuw voorbijgegaan aan datgene waarover op internationaal en Europees niveau overeenstemming werd bereikt. Volgens het VN-mensenhandelprotocol en het EUkaderbesluit dient immers uitsluitend de (mensenhandel met het oog op) gedwongen of verplichte arbeid of diensten, slavernij of met slavernij of dienstbaarheid te vergelijken praktijken aangepakt en strafbaar gesteld te worden. In tegenstelling tot de Raad van State, was de Regering er echter van overtuigd dat de strafbaarstelling van (mensenhandel met het oog op) tewerkstelling in omstandigheden die in

49 CGKR, Jaarrapport. Pleidooi voor een integrale benadering, analyse wetgeving en rechtspraak, december 2003, 70 .

50 Door de mensenhandelwet van 2005 worden de dwang en het misbruik van de kwetsbare situatie van de betrokkene immers niet langer weerhouden als constitutieve bestanddelen van het misdrijf mensenhandel. Het zijn enkel nog verzwarende omstandigheden. 
strijd zijn met de menselijke waardigheid ook slaat op de in het Protocol en Kaderbesluit vermelde vormen van uitbuiting op arbeidsvlak en bovendien strenger is..$^{51}$

Wat onder arbeidsomstandigheden die in strijd zijn met de menselijke waardigheid moet worden verstaan, wordt in artikel 433quinquies, paragraaf $\mathrm{I}, 3^{\circ} \mathrm{Sw}$. niet nader toegelicht. Volgens de memorie van toelichting bij de wet van 2005 gaat het niet om zwartwerk of om de illegale tewerkstelling die de sociale wetgeving schendt. Om vast te stellen of de arbeidsomstandigheden al dan niet in strijd zijn met de menselijke waardigheid, moeten volgens de memorie verschillende elementen in aanmerking worden genomen, zoals het loon, de werkomgeving en de arbeidsomstandigheden. Dat de arbeidsomstandigheden strijdig zijn met de menselijke waardigheid kan volgens de memorie onder meer worden afgeleid uit het feit dat de verstrekte diensten niet werden betaald, het loon kennelijk niet in verhouding staat tot het grote aantal verrichte arbeidsuren of lager ligt dan het gemiddeld maandelijkse minimuminkomen dat in de toepasselijke collectieve arbeidsovereenkomst werd vastgesteld. Hetzelfde geldt voor het geval één of meer werknemers in een arbeidsklimaat werken dat kennelijk niet in overeenstemming is met de normen die door de Wet van 4 augustus 1996 betreffende het welzijn van de werknemers bij de uitvoering van hun werk worden opgelegd..$^{2}$

Ondanks deze preciseringen, bleef de definitie van mensenhandel met het oog op arbeids- of dienstenexploitatie die uitsluitend spreekt over tewerkstelling in omstandigheden die in strijd zijn met de menselijke waardigheid bijzonder vaag. Bij ontbreken van een voldoende geoperationaliseerde, transparante juridische definitie wordt aan de politie, het OM en de feitenrechter immers een (al te) ruime appreciatiemarge gelaten en is het niet ondenkbeeldig dat de notie 'menselijke waardigheid', net zoals de notie 'misbruik van de bijzonder kwetsbare positie' uit het vroegere artikel 77 bis van de Vreemdelingenwet, op uiteenlopende wijze geïnterpreteerd wordt en aanleiding geeft tot (bewijs)problemen. Voor de politie en het OM is gepoogd meer houvast te creëren in een aangepaste omzendbrief van de minister van Justitie en het college van procureurs-generaal inzake het opsporings- en vervolgingsbeleid betreffende mensenhandel (COL I/2007), 53 die met ingang van I februari

5I In haar Advies vreest de Raad van State daarentegen dat een persoon die bijvoorbeeld een andere persoon in dienst zou nemen en daarbij misbruik zou maken van diens kwetsbare situatie of gebruik zou maken van dwang om een abnormale winst te generen, doch waarbij de omstandigheden waarin die tewerkstelling plaatsvindt niet strijdig kunnen worden geacht met de menselijke waardigheid, niet bestraft zal kunnen worden overeenkomstig artikel 433quinquies, par. I, $3^{\circ} \mathrm{Sw}$. (memorie van toelichting bij het Wetsontwerp van $\mathrm{I} 4$ januari 2005 tot wijziging van diverse bepalingen met het oog op de versterking van de strijd tegen mensenhandel en mensensmokkel, Parl. St. Kamer, 2004-2005, DOC 5 I I560/00I, 43-44).

52 Memorie van toelichting bij het Wetsontwerp van I4 januari 2005 tot wijziging van diverse bepalingen met het oog op de versterking van de strijd tegen mensenhandel en mensensmokkel, Parl. St. Kamer, 2004-2005, DOC 5I I560/00I, I9.

53 Zie in het bijzonder bijlage I ('Het begrip van het tewerkstellen in omstandigheden die in strijd zijn met de menselijke waardigheid'), 2. 
2007 de vorige omzendbriefCOL 10/2004 $4^{54}$ heeft vervangen. Volgens de omzendbrief moet er in voorkomend geval bewijs worden geleverd dat de arbeidsomstandigheden in kwestie 'een onderwerping of verlaging van de betrokken persoon tot gevolg heeft'. Onder 'onderwerping' wordt daarbij het feit verstaan 'dat een persoon onderworpen wordt aan dienstbaarheid, slavernij of extreme afhankelijkheid' (waarbij verwezen wordt naar definities uit het internationaal recht); onder 'verlaging' wordt 'de vernedering van een individu in het bijzijn van anderen of het feit aan te zetten tegen de wil of het geweten te handelen' begrepen. Ten behoeve van de opsporingsdiensten figureert als bijlage bij de omzendbrief verder een nuttige lijst van 'indicatoren die mensenhandel laten vermoeden', waaronder indicatoren met betrekking tot de arbeidsomstandigheden. ${ }^{55}$ De insteek op opsporings- en vervolgingsniveau lijkt daarmee nauwelijks meer gefocust dan de wet zelf.

Om uit te maken of de arbeidsomstandigheden al dan niet in strijd zijn met de menselijke waardigheid en er bijgevolg sprake is van economische uitbuiting, moet verder worden getoetst aan de normen, waarden en maatstaven zoals die bij ons gelden. Dit wordt eens te meer bevestigd in de omzendbrief COL I/2007 inzake het opsporings- en vervolgingsbeleid betreffende mensenhandel. De arbeidsomstandigheden in de landen van herkomst van de slachtoffers mogen daarbij niet in aanmerking worden genomen. Dat de illegale vreemdeling hier in België in (mogelijk veel) betere omstandigheden wordt tewerkgesteld en ondanks alles nog meer verdient dan in zijn thuisland, doet blijkbaar geen afbreuk aan het feit dat er in bepaalde gevallen toch sprake kan zijn van economische uitbuiting en bijgevolg mensenhandel. De aangehaalde omzendbrief verduidelijkt verder dat 'de eigen perceptie van het slachtoffer geen rol' speelt.

$\mathrm{Nu}$ de dwang of het misbruik van de bijzonder kwetsbare positie van de betrokkene niet langer vereist zijn voor de bestraffing van de mensenhandel met het oog op arbeids- of dienstenexploitatie, bestaat daarmee - althans theoretisch ${ }^{56}$ - het gevaar dat ordinaire zaken van zwartwerk of illegale tewerkstelling als mensenhandel vervolgd zouden (kunnen) worden. Op die manier zou de strijd tegen de mensenhandel afgewend worden van haar primaire doelstelling om mensen te beschermen tegen gedwongen of onvrije exploitatie..$^{57}$ De praktijk moet hier vertrouwen op een toepassing van de wet conform de memorie van toelichting (supra), zoals overigens in herinnering gebracht in omzendbrief COL r/2007 ('dat de wet van Io augustus 2005 een illegale werksituatie of zwartwerk niet als mensenhandel wenst te bestraffen').

54 FOD Justitie, OmzendbriefCOL Io/2004, Opsporings- en vervolgingsbeleid betreffende mensenhandel. Richtlijn van de minister van Justitie, 20 april 2004, Io p.

55 Bijlage 2, in de tekst van de omzendbrief zelf evenwel nog aangeduid als bijlage I, wellicht omdat het in wezen de overname betreft van de - wat economische uitbuiting betreft weliswaar bijgewerkte - indicatoren die als bijlage I waren gehecht aan de vorige omzendbrief Io/2004.

56 COL I/2007, bijlage I, 2.

57 CGKR, Rapport mensenhandel. Het Belgische mensenhandelbeleid: gewikt en gewogen, november 2005, 3I-32. 
Fundamenteel dient toch opgemerkt dat de stelling dat de arbeid die in strijd is met onze nationale normen en waarden (of zelfs: die van de EU) per definitie als economische uitbuiting moet worden beschouwd, afbreuk doet aan het zelfbeschikkingsrecht van personen, voor zover dit als absoluut moet worden beschouwd. Het is immers perfect mogelijk dat de illegale vreemdeling vrijwillig instemt met de omstandigheden waarin hij wordt tewerkgesteld. Indien achteraf blijkt dat deze niet overeenstemmen met de normen en waarden van de EU, is er misschien wel sprake van een inbreuk op de sociale wetgeving, die overeenkomstig het sociaal strafrecht gesanctioneerd kan worden, doch niet noodzakelijk van economische uitbuiting en mensenhandel. Mensenhandel betreft in eerste instantie immers gedwongen of onvrije exploitatie, die via de strafbaarstelling ervan moet worden aangepakt. Niet iedere zogenoemde consensuele exploitatie waarmee alle betrokken partijen instemmen, behoort derhalve aan de hand van de strafrechtelijke bepalingen inzake mensenhandel bestraft te worden.

Uit de prille praktijkervaring blijkt intussen dat de feitenrechter alvast niet al te snel tot mensenhandel met het oog op economische exploitatie besluit. Zonder in casuïstiek te vervallen,,$^{8}$ blijkt dat deze, 'alvorens te besluiten dat er sprake is van mensenhandel, met meerdere elementen rekening zal houden: de verloning, de werkomgeving en -omstandigheden, de huisvestingsomstandigheden en de afhankelijkheidssituatie ten aanzien van de werkgever'. ${ }^{59}$

Dat mensenhandel met het oog op arbeids- of dienstenexploitatie in artikel 433quinquies, paragraaf $\mathrm{I}, 3^{\circ} \mathrm{Sw}$. ten slotte beperkt wordt tot de gevallen waarin men aan het werk wordt gezet in omstandigheden die in strijd zijn met de menselijke waardigheid, is jammer. Met de wet van 2005 lijkt het immers niet mogelijk niet elke vorm van economische exploitatie aan de hand van deze nieuwe bepaling te bestraffen. Met name rijst de vraag in hoeverre mensenhandel met het oog op gedwongen arbeid of arbeid waarbij misbruik wordt gemaakt van de bijzonder kwetsbare positie van de betrokkene, zonder dat de omstandigheden waarin men wordt tewerkgesteld in strijd zijn met de menselijke waardigheid, nog bestraft zal kunnen worden.

c Mensenhandel met het oog op de orgaanhandel, de exploitatie in de bedelarij of het doen plegen van misdrijuen

Tegen alle verwachtingen in werd door de nieuwe mensenhandelwet, naast mensenhandel met het oog op seksuele of economische exploitatie of organen- of weefseldiefstal en -transplantatie, nog andere varianten van mensenhandel ingevoerd. ${ }^{6 \circ}$ Volgens artikel 433quinquies Sw. moet immers ook de werving, het vervoer, de overbrenging, de huisvesting, de opvang, de wisseling of de overdracht van een persoon

58 Voor een goed overzicht van rechtspraak per deelsector, zie: CGKR, Men\$enhandel - \$mokkel bestrijden met mensen en middelen. Jaarverslag 2008, Brussel, 64-70.

59 Ibidem, 64.

6o De strafbaarstelling van de mensenhandel met het oog op het (laten) wegnemen van organen of weefsels wordt enkel door het VN-mensenhandelprotocol, doch niet door het EU-kaderbesluit inzake mensenhandel verplicht gesteld. 
met het oog op diens exploitatie in de bedelarij door een ander of zelfs, in algemene zin, om hem te dwingen om het even welk(e) misdaad of wanbedrijf te plegen, als mensenhandel worden beschouwd. ${ }^{6 r}$

Beide strafbaarstellingen doen vragen rijzen. Vooreerst was er geen enkel internationaal of Europees rechtsinstrument dat tot strafbaarstelling van mensenhandel met het oog op exploitatie van bedelarij verplichtte of zelfs maar opriep. Bovendien komt de exploitatie van de bedelarij in feite neer op economische exploitatie en kan voormelde vorm van mensenhandel, indien dit nodig mocht blijken, zonder problemen aangepakt worden met behulp van artikel 433 quinquies, paragraaf $\mathrm{I}, 3^{\circ} \mathrm{Sw}$. dat mensenhandel met het oog op de exploitatie van arbeid of diensten strafbaar stelt. In die optiek lijkt de afzonderlijke strafbaarstelling van mensenhandel met het oog op exploitatie van bedelarij overbodig. Vandaar dat de vraag dient gesteld of de strafbaarstelling van mensenhandel gericht op exploitatie van bedelarij niet primair of minstens in belangrijke mate door motieven van 'morele' openbare orde was ingegeven en de bedoeling had bedelaars vanuit een zogenaamde mensenrechtelijke bekommernis gemakkelijker uit het straatbeeld te verjagen.

Dat strafbaarstelling van mensenhandel met de bedoeling het slachtoffer te dwingen een misdaad of een wanbedrijf te plegen, verbaast evenzeer. Een persoon dwingen om een misdrijf te plegen is uiteraard strafwaardig; alleen volstaan de bestaande regels inzake mededaderschap reeds om dit te bestraffen. ${ }^{62}$ Dat de persoon voorafgaand aan de dwang onder meer werd vervoerd of overgebracht, kan de afzonderlijke strafbaarstelling alvast niet verantwoorden. Op grond van het bewegingselement alleen kan immers niet besloten worden tot mensenhandel. ${ }^{63}$ De motivering in de memorie van toelichting bij de wet van 2005 dat deze nieuwe strafbaarstelling een eenvoudige bevestiging inhoudt van de 'moderne' invulling die door recente Belgische rechtspraak aan de notie mensenhandel werd gegeven in zaken van drugshandel en diefstallen, overtuigt evenmin. ${ }^{64}$ Bedoelde rechtspraak betrof immers gevallen van illegale binnenkomst waarbij overeenkomstig het voormalige artikel 77 bis van de Vreemdelingenwet misbruik werd gemaakt van de kwetsbare positie van de betrokkenen door hen te verplichten drugs te verkopen of diefstallen te plegen, terwijl hen een totaal ander takenpakket was voorgespiegeld. De veroordeling voor mensenhandel werd dus niet gebaseerd op

6I $\mathrm{Nu}$ de mensenhandelwet van 2005 de exploitatievormen waarop de mensenhandel gericht kan zijn, aanzienlijk heeft uitgebreid, is het verwonderlijk dat niet ook de kinderhandel met het oog op illegale adoptie - dat naar verluid nochtans een reëel probleem blijkt te zijn - strafbaar wordt gesteld.

62 Overeenkomstig artikel 66, lid 3 Sw. moeten diegenen die door giften, beloften, bedreigingen, misbruik van gezag of van macht, misdadige kuiperijen of arglistigheden, de misdaad of het wanbedrijf rechtstreeks hebben uitgelokt immers als daders van de misdaad of het wanbedrijf worden bestraft.

63 Dit wordt bevestigd door de Expertengroep Mensenhandel van de Europese Commissie in haar rapport van 22 december 2004 (Commission of the European Communities, Report of the Experts Group on Trafficking in Human Beings, Brussel, 22 december 2004), 48.

64 Memorie van toelichting bij het Wetsontwerp van I4 januari 2005 tot wijziging van diverse bepalingen met het oog op de versterking van de strijd tegen mensenhandel en mensensmokkel, Gedr. St. Kamer, 2004-2005, DOC 5I I560/00I, 20. 
het feit dat de betrokkenen gedwongen waren om misdrijven te plegen, maar volgde uit de vaststelling dat de mensensmokkel gepaard ging met dwang, misleiding of onvrijheid. Het ander motief dat in de memorie wordt aangehaald, met name dat het Verdrag nr. I82 van de Internationale Arbeidsorganisatie verbiedt dat kinderen worden gebruikt, aangeworven of aangeboden voor ongeoorloofde praktijken, zoals de drugproductie en -handel, kan de strafbaarstelling van mensenhandel met de bedoeling de betrokkene te dwingen een misdaad of wanbedrijf te plegen, ook moeilijk verantwoorden daar dit Verdrag enkel betrekking heeft op kinderen. ${ }^{65}$ Op grond van de voorgaande overwegingen kan de vraag gesteld worden of deze mensenhandelvariant niet in eerste instantie bedoeld was om beter en repressiever te kunnen optreden tegen diegenen die zich van (economisch) kwetsbare en bijgevolg gemakkelijk vervangbare personen (uit derde landen) bedienen om voor hun rekening hier misdrijven te plegen. In dat geval zou de strijd tegen mensenhandel van zijn primaire doelstelling worden afgewend en eerder gebruikt worden voor een meer efficiënte repressie van criminaliteitsfenomenen die men anders maar moeilijk onder controle krijgt.

De prille praktijkervaring met de nieuwe wet (over het jaar 2008) laat alvast zien dat er bijzonder weinig gevallen zijn (waarin het OM wordt gevat) van mensenhandel gericht op exploitatie in de bedelarij (I2 zaken, ofwel o, 28 procent van het totaal aantal zaken mensenhandel of -smokkel, waarvan uiteindelijk geen enkel heeft geleid tot een procedure voor de feitenrechter), op het doen plegen van misdrijven (3I zaken, ofwel 0,73 procent van het totaal aantal zaken mensenhandel of -smokkel, waarvan in één ervan werd gedagvaard voor de feitenrechter) of op organen- of weefseldiefstal of -transplantatie (één vooronderzoek, dat nog loopt). De problemen in deze sferen zijn duidelijk niet groot, of men slaagt er niet in ze in beeld te krijgen en succesvol af te ronden. Drie jaar na de nieuwe wet kan dit toch tellen.

In tegenstelling tot hetgeen men - gelet op de internationale en Europese mensenhandeldefinities - zou verwachten, vereist artikel 433quinquies Sw. niet dat er een element van dwang of onvrijheid aanwezig is opdat er sprake zou zijn van mensenhandel. ${ }^{66}$ Mensenhandel behoeft uitsluitend een bewegings- en uitbuitingselement. Voor de strafbaarheid op zich wordt dus niet vereist dat de mensenhandel gepaard ging met het gebruik van listige kunstgrepen, geweld, bedreigingen of enige vorm van dwang of het misbruik van de bijzonder kwetsbare positie van het slachtoffer: het betreffen hier 'slechts' verzwarende omstandigheden die er enkel toe leiden dat de mensenhandel strenger wordt bestraft. Volgens de internationale en Europese mensenhandeldefinities en de EU deskundigengroep mensenhandel is dwang en onvrijheid nochtans een wezenskenmerk van mensenhandel, en kan er bij gebrek daaraan niet gesproken worden van mensenhandel. De mensenhandeldefinitie in artikel 433 quinquies Sw. druist daar nu tegen in. In de memorie van toelichting bij

65 Internationale Arbeidorganisatie, Verdrag nr. I82 van 17 juni 1999 inzake de ergste vormen van kinderarbeid.

66 In tegenstelling tot hetgeen in het voormalige artikel 77bis Vreemdelingenwet werd bepaald. 
de wet van 2005 wordt dit verantwoord door erop te wijzen dat de internationale en Europese mensenhandeldefinities slechts minimumnormen bepalen, en de Belgische wetgever niet beletten verder te gaan, hetgeen hij ook deed. Alleen kan men zich afvragen waarom dan op internationaal en Europees niveau jarenlang werd onderhandeld over een mensenhandeldefinitie waarin iedereen zich zou kunnen vinden. ${ }^{67}$ Volgens de memorie wordt het feit dat dwang of onvrijheid niet als constitutief element van het misdrijf mensenhandel werd weerhouden, bovendien gecompenseerd door de toevoeging in de strafbaarstelling van de voorgenomen of daadwerkelijke uitbuiting als nieuw bestanddeel van het misdrijf. ${ }^{68}$ Alleen komt uit artikel 433quinquies Sw. zelf niet duidelijk naar voor dat de voorgenomen of daadwerkelijke uitbuiting een nieuw bestanddeel is van het misdrijf. Evenmin is het duidelijk wat met voorgenomen of daadwerkelijke uitbuiting wordt bedoeld. Vast staat dat deze niet kan worden afgeleid uit het ontbreken van de toestemming van het slachtoffer, noch uit de aanwezigheid van dwang, geweld, bedreigingen of het feit dat misbruik werd gemaakt van de bijzonder kwetsbare positie van het slachtoffer. De toestemming van het slachtoffer, het gebruik van dwangmiddelen of het misbruik van de kwetsbare positie van het slachtoffer zijn op zich immers niet relevant om uit te maken of al dan niet sprake is van mensenhandel. Bijgevolg moet worden aangenomen dat met 'voorgenomen of daadwerkelijke uitbuiting' wordt bedoeld dat men uit de mensenhandelactiviteit profijt moet willen halen of dat er profijt mee wordt gedaan. Dit houdt in dat winst(oogmerk) voortaan als een bestanddeel van de mensenhandeldefinitie wordt beschouwd, terwijl de internationale en Europese rechtsinstrumenten ter zake net zeggen dat het winstoogmerk een wezenskenmerk is van mensensmokkel en niet van mensenhandel, en dat mensenhandel, ook bij afwezigheid van een winstoogmerk, strafbaar gesteld moet worden. Ook hier wijkt de Belgische mensenhandeldefinitie van 2005 af van hetgeen waarover op internationaal en Europees niveau consensus bestaat. Meer zelfs, de wet van 2005 schiet op dit punt ontegenzeggelijk als implementatiebepaling tekort.

Als gevolg van de ruime(re) formulering van de exploitatievormen waarop mensenhandel gericht kan zijn, wordt het toepassingsgebied ervan aanzienlijk uitgebreid. Behalve seksuele exploitatie, arbeidsexploitatie en orgaan- of weefseldiefstal en -transplantatie worden ook de exploitatie van de bedelarij en het plegen van een misdaad of wanbedrijf als mogelijke doeleinden van mensenhandel naar voor geschoven. Deze verruiming van het toepassingsgebied van mensenhandel houdt echter een aantal risico's in.

67 Daarbij komt nog dat het EU-Kaderbesluit inzake mensenhandel dat ijvert voor een gemeenschappelijke definitie van mensenhandel voor alle EU lidstaten, in feite voortvloeit uit het Gemeenschappelijk Optreden van 24 februari 1997 ter bestrijding van mensenhandel en seksuele uitbuiting van kinderen, dat op Belgisch initiatief werd aangenomen.

68 Memorie van toelichting bij het Wetsontwerp van I4 januari 2005 tot wijziging van diverse bepalingen met het oog op de versterking van de strijd tegen mensenhandel en mensensmokkel, Gedr. St,. Kamer, 2004-2005, 5I- I560/00I, 2 I. 
Bijgevolg rijst ook het gevaar dat meer personen aanspraak zullen (proberen) maken op het bijzonder slachtofferstatuut mensenhandel dat op die manier dreigt uitgehold te worden. In dat geval zou aan de 'echte' slachtoffers van mensenhandel minder aandacht en zorg besteed kunnen worden. In die optiek moet er over gewaakt worden dat de strijd tegen mensenhandel zo zuiver mogelijk wordt gehouden en toegespitst blijft op de 'echte' gevallen van mensenhandel.

Een andere oorzaak van de ruime(re) strafbaarstelling van mensenhandel is gelegen in het feit dat er voor mensenhandel niet langer sprake hoeft te zijn van dwang of onvrijheid in hoofde van het slachtoffer. Het bewegings- en uitbuitingselement volstaan voor mensenhandel. Dwang of onvrijheid moet voortaan niet meer worden aangetoond. ${ }^{69}$ Nochtans dient benadrukt dat geweld, dwang, onvrijheid, misleiding, bedrog of misbruik van de kwetsbare positie van het slachtoffer de essentie uitmaken van mensenhandel en dat in het kader van de strijd tegen mensenhandel in eerste instantie moet worden opgetreden tegen de gedwongen of onvrije exploitatie die de menselijke waardigheid schendt. ${ }^{\circ}$

Gelet op het zelfbeschikkingsrecht van mensen, kan men zich bovendien vragen stellen bij de noodzaak om de zogenoemde consensuele exploitatie waarmee alle betrokken partijen instemmen, strafbaar te stellen. Niettemin heerst er in de (handhavings)praktijk grote tevredenheid met het feit dat dwang of onvrijheid niet langer als wezenskenmerk van mensenhandel wordt beschouwd, daar dit de bewijslast van het OM aanzienlijk verlicht en vrijspraken wegens een gebrek aan bewijs van dwang of onvrijheid zo vermeden kunnen worden..$^{\text {I }}$

Bovendien is het op termijn allerminst ondenkbaar dat, nu dwang of onvrijheid niet meer moeten worden bewezen, minder een beroep gedaan zal moeten worden op getuigenissen van slachtoffers over dwang of onvrijheid die zij ondergingen. In de praktijk blijken immers steeds minder slachtoffers bereid om mee te werken met de gerechtelijke autoriteiten en in het kader van een strafprocedure tegen hun mensenhandelaar(s) verklaringen of getuigenissen af te leggen. Zij voelen zich vaak geen slachtoffer van mensenhandel wanneer zij initieel met de exploitatie hebben ingestemd, en willen als zodanig ook niet erkend worden. Vandaar dat ze er in het kader van een strafrechtelijke procedure ook minder belang bij hebben verklaringen of getuigenissen af te leggen.

69 Voor een veroordeling op grond van artikel 77 bis van de Vreemdelingenwet moest vroeger immers het bewijs worden geleverd van dwang of onvrijheid in hoofde van het slachtoffer. Voor de bestraffing op zich moet niet langer worden bewezen dat het slachtoffer op en of andere manier werd gedwongen of onvrij was. Gebeurt dit toch, dan leidt dit overeenkomstig artikel 433 septies, $2^{\circ}$ en $3^{\circ}$ Sw. tot een strengere bestraffing van de mensenhandel.

70 Deze stelling wordt ondersteund door het VN-mensenhandelprotocol van I5 november 2000, het EU-kaderbesluit inzake mensenhandel van I9 juli 2002 en de Expertengroep Mensenhandel.

7I Tijdens de besprekingen over de wetswijzigingen in de Senaatscommissie Justitie kwam immers naar voor dat het OM in het verleden soms moeilijkheden ondervond om de dwang of onvrijheid in hoofde van het slachtoffer van mensenhandel te bewijzen en een veroordeling te bekomen op grond van artikel 77 bis van de Vreemdelingenwet. 
De vraag is of de huidige mensenhandeldefinitie in de praktijk niet schadelijk is voor diegenen die wel degelijk het slachtoffer waren van uitbuiting, ongeacht hun oorspronkelijke instemming met de exploitatie. Ook op deze slachtoffers zal het OM minder een beroep moeten - en op termijn misschien ook gaan - doen om het mensenhandelmisdrijf te bewijzen.

Bovendien wordt gevreesd dat belangrijke mensenhandeldossiers waarin door een mensenhandelaar bvb. gebruik werd gemaakt van geweldplegingen of bedreigingen met represailles - die moeilijker te bewijzen zijn en waarvoor doorgaans een beroep moet worden gedaan op de verklaringen van de slachtoffers - op een secundaire manier behandeld zullen worden, met alle negatieve gevolgen van dien voor de slachtoffers..$^{72}$ Het is maar de vraag of de nieuwe omzendbrief COL $1 / 2007$, die allerminst ondubbelzinnig voorrang vraagt voor gevallen van gedwongen of onvrije exploitatie, daar op termijn een voldoende middel toe zal blijken.

In het Actieplan Mensenhandel van $2008{ }^{73}$ wordt de retorische vraag gesteld of 'de uitbreiding van de definitie van mensenhandel de bewijslast inzake mensenhandel [vergemakkelijkt]?'. Wij dachten van wel dus.

\title{
3.2.2 Nieuwe strafbaarstelling mensensmokkel
}

Zoals gezegd had men met de nieuwe mensenhandelwet onder meer tot doel in de wet een duidelijker onderscheid te maken tussen mensenhandel enerzijds en mensensmokkel anderzijds. Zo werd de strafbaarstelling van mensenhandel volledig overgeheveld naar de Strafwet, en wordt in het nieuw ingevoegde artikel 77 bis Vreemdelingenwet voortaan nog uitsluitend de mensensmokkel strafbaar gesteld. Net zoals voor mensenhandel in artikel 433quinquies Sw., wordt in artikel 77bis Vreemdelingenwet voor het eerst expliciet gedefinieerd wat onder mensensmokkel moet worden verstaan. Volgens het artikel maakt men zich schuldig aan mensensmokkel wanneer men er

\begin{abstract}
'op welke manier ook toe bijdraagt, rechtstreeks of via een tussenpersoon, dat een persoon die geen onderdaan is van een lidstaat van de Europese Unie of van een Staat die partij is bij een internationale overeenkomst betreffende de overschrijding van de buitengrenzen, die België bindt, binnenkomt, erdoor reist of aldaar verblijft, zulks in strijd met de wetgeving van deze Staat, met het oog op het direct of indirect verkrijgen van een vermogensvoordeel'.
\end{abstract}

Zoals de internationale en Europese rechtsinstrumenten ter zake vereisen, maken de (illegale) grensoverschrijding en het winstoogmerk volgens artikel 77bis Vreemdelingenwet de wezenskenmerken uit van mensensmokkel. Bovendien wordt voor

72 CGKR, Rapport mensenhandel. Het Belgische mensenhandelbeleid: gewikt en gewogen, november 2005, 25 .

73 Koninkrijk België, De strijd tegen mensenhandel en mensensmokkel - Actieplan, Brussel, 2008. 
het eerst een duidelijk onderscheid gemaakt tussen mensensmokkel en de loutere hulp bij illegale immigratie. Dergelijke hulp wordt afzonderlijk strafbaar gesteld in artikel 77 Vreemdelingenwet en wordt omschreven als de hulp die bij de illegale binnenkomst, illegale doortocht of het illegaal verblijf van vreemdelingen in België wordt verstrekt zonder dat er, zoals bij mensensmokkel, sprake is van een winstoogmerk. ${ }^{74}$ Alleen wanneer de hulp bij illegale immigratie voornamelijk om humanitaire redenen wordt verstrekt, kan men niet bestraft worden.

Opnieuw is de Belgische regelgeving strenger dan hetgeen op Europees niveau wordt voorgeschreven. In tegenstelling tot hetgeen door de Europese richtlijn van 28 november 2002 wordt voorgeschreven, wordt door artikel 77bis Vreemdelingenwet niet alleen de hulp bij het illegaal verblijf, maar ook de hulp bij de illegale binnenkomst en doortocht strafbaar gesteld voor zover deze hulpverlening gepaard gaat met een winstoogmerk. In afwijking van de Europese richtlijn wordt in artikel 77 Vreemdelingenwet bovendien niet alleen de hulpverlening bij de illegale binnenkomst of doortocht, doch ook de hulpverlening bij het illegaal verblijf zonder winstoogmerk, strafbaar gesteld. Anderzijds wordt wel bepaald dat wanneer de hulp bij het illegaal verblijf zonder winstoogmerk voornamelijk om humanitaire redenen wordt verstrekt, men niet bestraft kan worden. Op die manier geeft Artikel 77 Vreemdelingenwet een ruimere invulling aan de zogenaamde humanitaire clausule dan de Europese richtlijn, die deze uitzondering niet voorziet. ${ }^{75}$

\subsubsection{Verzwaarde straffen voor mensenhandel en mensensmokkel}

Door de Wet van Io augustus 2005 werd niet alleen de strafbaarstelling van mensenhandel aanzienlijk uitgebreid, ook de straffen voor de mensenhandel werden opnieuw verstrengd. Overeenkomstig artikel 433quinquies, paragraaf 2 Sw. dient mensenhandel - als basismisdrijf - immers bestraft te worden met een gevangenisstraf van I tot 5 jaar en met een geldboete van 500 tot 50.000 euro..$^{6}$ Voorheen werd mensenhandel, al naar gelang het geval, bestraft aan de hand van de artt. 380 Sw. en 77 bis Vreemdelingenwet, die voor het basismisdrijf een gevangenisstraf van I tot 5 jaar en een geldboete van 500 tot 25.000 euro voorzagen. Ook voor de poging wordt door artikel 433quinquies, paragraaf 3 Sw., in vergelijking met artikel 380 , paragraaf 2 Sw., een strengere strafmaat bepaald: deze dient bestraft te worden met een gevangenisstraf van I tot 3 jaar en met een geldboete van roo tot 10.000 euro. ${ }^{7}$ De strengere bestraffing van de mensenhandel volgt bovendien niet alleen uit de

74 Het nieuwe artikel 77 Vreemdelingenwet voorziet daarvoor in een gevangenisstraf van 8 dagen tot I jaar en/of een geldboete van $€$ I70o tot 6000 .

75 Zie ook: CGKR, Rapport mensenhandel. Het Belgische mensenhandelbeleid: gewikt en gewogen, november 2005, I4-I5.

76 Het betreft hier dus een wanbedrijf waarvoor de correctionele rechtbank bevoegd is.

77 Voor de poging tot mensenhandel met het oog op de seksuele exploitatie van het slachtoffer wordt door artikel 380, par. 2 Sw. een gevangenisstraf van 6 maanden tot 3 jaar en een geldboete van 100 tot 5000 euro bepaald. Het voormalige artikel 77 bis Vreemdelingenwet daarentegen stelde de poging niet strafbaar. 
strengere strafmaat die voor het basismisdrijf is bepaald, doch ook uit de aanzienlijke uitbreiding van het aantal verzwarende omstandigheden dat voor de mensenhandel in de artt. 433 sexies tot en met octies Sw. wordt bepaald en die een strengere bestraffing tot gevolg hebben..$^{8}$

Behalve voor mensenhandel, werd door de Wet van Io augustus 2005 ook voor mensensmokkel in een strengere strafmaat voorzien. Voortaan dient mensensmokkel overeenkomstig het nieuwe artikel 77 bis Vreemdelingenwet en naar analogie met mensenhandel in artikel 433quinquies, paragraaf 2 Sw. bestraft te worden met een gevangenisstraf van I tot 5 jaar en met een geldboete van 500 tot 50.000 euro. Voorheen diende mensensmokkel op grond van het voormalige artikel 77 Vreemdelingenwet immers bestraft te worden met een gevangenisstraf van 8 dagen tot 3 maanden en/of met een geldboete van 1.700 tot 6.000 euro. Bovendien werd voor het eerst ook de poging tot mensensmokkel strafbaar gesteld met dezelfde straffen als de poging tot mensenhandel, met name een gevangenisstraf van I tot 3 jaar en een geldboete van Ioo tot 10.000 euro. Zowel het voltooide misdrijf als de poging tot mensensmokkel komen voortaan dus in aanmerking voor overlevering, zoals door het EU-Kaderbesluit van 28 november 2002 (toen nog, voorafgaand aan de inwerkingtreding van het Europees aanhoudingsbevel, met betrekking tot uitlevering) werd verplicht gesteld. Ook voor mensensmokkel werd in de artikelen $77_{\text {ter }}$ tot en met quinquies Vreemdelingenwet een groot aantal nieuwe verzwarende omstandigheden ingevoerd die dezelfde zijn als deze voor de mensenhandel in de artikelen 433 sexies tot en met octies Sw. en leiden tot een strengere bestraffing.

Een strenge strafmaat zal ongetwijfeld bijdragen tot de strijd tegen de mensenhandel en -smokkel. Vreemd is wel dat de strafmaat voor de mensenhandel en mensensmokkel werd gelijkgeschakeld en voor beide voortaan in dezelfde (nieuwe) verzwarende omstandigheden wordt voorzien. Met de afzonderlijke strafbaarstelling van de mensenhandel en mensensmokkel in de Strafwet, respectievelijk de Vreemdelingenwet, had de Wet van ro augustus 2005 immers tot doel het onderscheid tussen mensenhandel en -smokkel duidelijk te stellen. Door voor beide in dezelfde

78 Nieuwe verzwarende omstandigheden zijn: het feit dat de mensenhandelaar een gezagsfunctie heeft ten aanzien van het slachtoffer of een zekere openbare functie bekleedt; het feit dat het slachtoffer minderjarig is; het feit dat het leven van het slachtoffer door de mensenhandelaar opzettelijk of door grove nalatigheid in gevaar is gebracht, het feit dat de mensenhandel een ongeneeslijk lijkende ziekte, hetzij een blijvende fysieke of psychische ongeschiktheid, hetzij het volledig verlies van een orgaan of van het gebruik van een orgaan, hetzij een zware verminking, hetzij de dood van het slachtoffer heeft veroorzaakt; en het feit dat de betrokken activiteit het werk is van een criminele organisatie. Andere verzwarende omstandigheden, die ook door de artikelen 380 en 38I Sw. worden voorzien, zijn: het feit dat door de mensenhandelaar (in)direct gebruik werd gemaakt van listige kunstgrepen, geweld, bedreigingen of enige andere vorm van dwang, of misbruik werd gemaakt van de bijzondere kwetsbare positie waarin het slachtoffer om bepaalde redenen verkeerde; en het feit dat de mensenhandel de hoofd- of bijkomende bedrijvigheid uitmaakte van een vereniging. Een laatste verzwarende omstandigheid, die ook reeds door het voormalige artikel 77 bis Vreemdelingenwet werd voorzien, betreft het feit dat van de mensenhandelactiviteit een gewoonte werd gemaakt (voor meer uitleg bij de verzwarende omstandigheden: zie infra) 
strafmaat en dezelfde verzwarende omstandigheden te voorzien, wordt het onderscheid tussen mensenhandel en -smokkel door diezelfde wet gedeeltelijk terug tenietgedaan. ${ }^{79}$ Volgens de memorie van toelichting bij de wet echter is de gelijkschakeling van de strafmaat en de verzwarende omstandigheden voor mensenhandel en mensensmokkel goed voor de samenhang en bovendien verantwoord daar mensenhandel en mensensmokkel vaak in gelijkaardige omstandigheden plaatsvinden en in dezelfde mate de gezondheid en het leven van de slachtoffers in gevaar (kunnen) brengen. ${ }^{80}$ Toch dient opgemerkt dat met de gelijkschakeling van de strafmaat en verzwarende omstandigheden voor mensenhandel en mensensmokkel niettemin voorbij wordt gegaan aan het wezenlijke verschil tussen mensenhandel en mensensmokkel. Bovendien bestaat het gevaar dat het OM in de toekomst - ook in geval van mensenhandel - eerder of minstens parallel zal gaan vervolgen voor mensensmokkel, dat voor de rechtbank doorgaans gemakkelijker en zonder dat een beroep moet worden gedaan op het slachtoffer, bewezen kan worden. De strafmaat voor beide misdrijven is immers dezelfde. Op termijn is bijgevolg het risico reëel dat nog maar weinig slachtoffers van mensenhandel aanspraak zullen kunnen maken op het bijzonder slachtofferstatuut en als dusdanig erkend zullen worden.

Eindelijk werd ook in het Actieplan Mensenhandel van $2008^{8 \mathrm{r}}$ vastgesteld dat het feit dat op het vlak van mensenhandel en mensensmokkel dezelfde strafdrempels bestaan, misschien niet zo geschikt is. De vraag wordt er gesteld of 'de minimale strafdrempel bij mensensmokkel niet verminderd moeten worden?'. Ja dus. Of het gebeurt, is een andere zaak.

\subsubsection{Onderscheid mensenhandel en mensensmokkel}

Zoals gezegd, werd met de Wet van 2005 getracht het onderscheid tussen mensenhandel en -smokkel duidelijk(er) te stellen. Zo werd de strafbaarstelling van mensenhandel volledig overgeheveld naar de Strafwet en wordt in artikel 77 bis van de Vreemdelingenwet voortaan nog uitsluitend mensensmokkel strafbaar gesteld. Net zoals voor mensenhandel in artikel 433quinquies Sw., wordt in artikel 77 bis van de Vreemdelingenwet voor het eerst expliciet omschreven wat onder mensensmokkel moet worden verstaan. Geheel in overeenstemming ook met de internationale en Europese rechtsinstrumenten ter zake, maken de (illegale) grensoverschrijding of binnenkomst en het winstoogmerk volgens artikel 77 bis van de Vreemdelingenwet de wezenskenmerken uit van mensensmokkel. Bovendien wordt voor het eerst een duidelijk onderscheid gemaakt tussen mensensmokkel en de loutere hulp bij

79 Bovendien zijn het gebruik van dwang en het misbruik dat van de bijzonder kwetsbare situatie van het slachtoffer wordt gemaakt, ook voor de mensensmokkel verzwarende omstandigheden, terwijl dit net wezenlijke kenmerken van mensenhandel zijn. Uiteraard komt ook dit het duidelijk onderscheid tussen mensenhandel en -smokkel niet ten goede.

8o Memorie van toelichting bij het Wetsontwerp van I4 januari 2005 tot wijziging van diverse bepalingen met het oog op de versterking van de strijd tegen mensenhandel en mensensmokkel, Gedr. St., Kamer, 2004-2005, 5I- I56o/00I, II en 30.

8I Koninkrijk België, De strijd tegen mensenhandel en mensensmokkel-Actieplan, Brussel, 2008. 
illegale immigratie, die strafbaar wordt gesteld in artikel 77 van de Vreemdelingenwet en neer komt op de hulp die bij de illegale binnenkomst, illegale doortocht of het illegaal verblijf van vreemdelingen in België wordt verstrekt zonder dat er, zoals bij mensensmokkel, sprake is van een winstoogmerk. Alleen wanneer de hulp bij illegale immigratie voornamelijk om humanitaire redenen wordt verstrekt, kan men niet bestraft worden. ${ }^{82}$

Toch diende opgemerkt dat het onderscheid tussen mensenhandel en -smokkel door de wet van 2005 voor een stuk opnieuw teniet wordt gedaan doordat voor beide voortaan in dezelfde strafmaat en dezelfde (nieuwe) verzwarende omstandigheden wordt voorzien. Bovendien zijn het gebruik van dwang en het misbruik dat van de bijzonder kwetsbare situatie van het slachtoffer wordt gemaakt, ook voor de mensensmokkel verzwarende omstandigheden, terwijl dit net wezenlijke kenmerken van mensenhandel zijn.

Het onderscheid de jure tussen mensenhandel en mensensmokkel staat daarmee ook na de nieuwe mensenhandelwet nog niet helemaal op punt, zodat in de toepassing ervan nog steeds tot op zekere hoogte een vermenging van de concepten blijft optreden.

Wanneer men bovendien het ruimer (strafrechtelijk) beleid beziet, is het gebrek aan een de facto onderscheid nog problematischer. Gezien beide fenomenen in de praktijk nog steeds integraal worden benaderd, is de aanpak van mensenhandel bijzonder sterk verweven met de strijd tegen mensensmokkel. Uiteraard kan het niet anders dan dat dit de vermenging van beide concepten in de hand werkt.

Bij Koninklijk Besluit van 16 mei $2004^{8_{3}}$ werd beslist om de rol van de Interdepartementale Coördinatiecel in het kader van de strijd tegen de mensenhandel terug te versterken en haar tevens in te schakelen in de strijd tegen de mensensmokkel. ${ }^{8}{ }^{4}$ Vandaag heeft de Interdepartementale Coördinatiecel de belangrijke opdracht om het geïntegreerde beleid inzake de strijd tegen de mensenhandel en -smokkel concreet

82 Opnieuw is de Belgische regelgeving strenger dan hetgeen op Europees niveau is bepaald. In tegenstelling tot hetgeen door de Europese richtlijn van 28 november 2002 wordt voorgeschreven, wordt door artikel 77 bis van de Vreemdelingenwet niet alleen de hulp bij het illegaal verblijf, maar ook de hulp bij de illegale binnenkomst en doortocht strafbaar gesteld voor zover deze hulpverlening gepaard gaat met een winstoogmerk. In afwijking van de Europese richtlijn wordt in artikel 77 van de Vreemdelingenwet bovendien niet alleen de hulpverlening bij de illegale binnenkomst of doortocht, doch ook de hulpverlening bij het illegaal verblijf zonder winstoogmerk, strafbaar gesteld. Anderzijds wordt wel bepaald dat wanneer de hulp bij het illegaal verblijf zonder winstoogmerk voornamelijk om humanitaire redenen wordt verstrekt, men niet bestraft kan worden. Op die manier geeft Artikel 77 van de Vreemdelingenwet een ruimere invulling aan de zogenaamde humanitaire clausule dan de Europese richtlijn die deze uitzondering niet voorziet.

83 Koninklijk Besluit van I6 mei 2004 betreffende de bestrijding van de mensensmokkel en mensenhandel, B.S. 28 mei 2004.

84 Deze Interdepartementale Coördinatiecel ter bestrijding van de mensenhandel werd initieel opgericht bij Koninklijk Besluit van I6 juni 1995 tot uitvoering van artikel II, par. 5, van de Wet

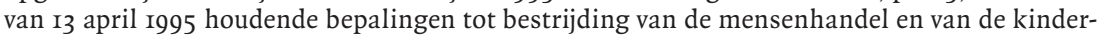
pornografie (B.S. I4 juli 1995). In de loop der jaren verdween deze cel echter naar de achtergrond. 
gestalte te geven, en heeft ze in dat verband zowel een beleidsuitvoerende als -voorbereidende taak.

Tegelijk werd voorzien in de oprichting van een Informatie- en Analysecentrum Mensensmokkel en Mensenhandel (IAMM) die moet instaan voor de verzameling, centralisering en vlotte uitwisseling van alle informatie over zowel mensenhandel als mensensmokkel, waarop tevens strategische analyses zullen uitgevoerd worden.

Bij hetzelfde Koninklijk Besluit werden ook de bevoegdheden van het Centrum voor gelijkheid van kansen en voor racismebestrijding (CGKR) uitgebreid. Sindsdien staat het CGKR in voor de bevordering, coördinatie en opvolging van het beleid ter bestrijding van zowel de mensenhandel als -smokkel en moet zij jaarlijks een evaluatieverslag opmaken over de evolutie en de resultaten van de bestrijding van beide fenomenen. ${ }^{85}$ Verder dient de Regering in haar tweejaarlijks rapport aan het Parlement voortaan niet alleen verslag uit te brengen over de toepassing van de mensenhandelwet en de bestrijding van de mensenhandel, doch ook over de strijd tegen de mensensmokkel. ${ }^{86}$

Gelet op het eerder aangehaalde wezenlijke onderscheid tussen mensenhandel en (niet-problematische) mensensmokkel, is de beleidsoptie om ook de gevallen van mensensmokkel die niet gepaard gaan met een situatie van dwang of misbruik onder de bevoegdheid te brengen van de Interdepartementale Coördinatiecel, het IAMM en het CGKR betwistbaar. Hoewel het logisch lijkt om deze organen in te schakelen in zowel de strijd tegen mensenhandel als mensensmokkel in mensenhandelachtige omstandigheden, verdient het aanbeveling om een duidelijk onderscheid te maken met niet-problematische gevallen van mensensmokkel. Zo niet bestaat het risico dat de confusie tussen beide fenomenen de facto grotendeels overeind blijft.

Ten slotte gaan het aan de nieuwe omzendbrief COL I/2007 (die de vroegere COL Io/2004 heeft aangepast aan en beperkt tot de expliciete strafbaarstelling van mensenhandel in artikel 433quinquies Sw.) gehechte eenvormige registratieformulier op basis waarvan de databank mensenhandel van de federale politie gevoed wordt (waarop nog expressis verbis te lezen staat dat het gebaseerd is op de vorige omzendbrief COL Io/2004), de hernieuwde Interdepartementale Coördinatiecel en het IAMM nog steeds uit van de vroegere definitie van mensenhandel uit de artikel 379, 380, paragraaf I, I, 2 en 3 Sw. en artikel 77 bis Vreemdelingenwet. Inmiddels vijf jaar na de wet van 2005 , blijven deze - toen nieuwe - instrumenten en initiatieven

85 De Wet van I5 februari 1993 tot oprichting van een Centrum voor Gelijkheid van Kansen en voor Racismebestrijding (B.S. I9 februari I993) werd in die zin aangepast door de Wet van Io augustus 2005 en bepaalt nu dat het Centrum behalve de strijd tegen de mensenhandel, ook de strijd tegen de mensensmokkel dient te stimuleren en bevoegd is om in rechte op te treden in alle rechtsgeschillen waartoe de toepassing van de Wet van 13 april 1995 tot bestrijding van de mensenhandel én de mensensmokkel aanleiding kan geven. In dit verband dient erop gewezen dat het feit dat het Centrum voortaan is ingeschakeld in de strijd tegen de mensensmokkel, moeilijk te rijmen valt met haar andere taken in het kader van de strijd tegen racisme en xenofobie.

86 Artikel 40 van de Wet van Io augustus 2005. 
ongewijzigd. Het is duidelijk dat ze dringend moeten worden herbekeken, zoals dat in 2007 uiteindelijk is gebeurd met de omzendbrief van de minister van Justitie en het college van procureurs-generaal. Het besef daarover leeft wel. Het Actieplan Mensenhandel van $2008^{87}$ stipt aan dat de wet van 13 april 1995, waarop de werking van de Interdepartementale Cel teruggaat en die ook nog steeds het actiebereik van het CGKR mee bepaalt, 'nog referenties [bevat] die naar aanleiding van de stemming van de wet van ro augustus 2005 niet werden aangepast'. Het is wachten nu ...

\subsubsection{Rechtsmacht}

De wet van Io augustus 2005 heeft geen conceptuele veranderingen aan het opzet van artikel roter V.T. Sv. aangebracht. Wel heeft de wet - geheel naar verwachting eigenlijk - het toepassingbereik van de sinds 1995 bestaande en nadien bijgestelde universele rechtsmachtsgrond voor mensenhandel verruimd naar de nieuw geïntroduceerde expliciete strafbaarstellingen. ${ }^{88}$ Concreet werden in punt $\mathrm{I}^{\circ}[\ldots .$.$] de woor-$ den 'en 383bis, paragraaf I en 3, van het Strafwetboek' vervangen door de woorden ' 383 bis, paragraaf I en 3, 433sexies, 433septies en 433octies van het Strafwetboek', en in punt $3^{\circ}$ de woorden 'in artikel 77 bis, paragraaf 2 en 3 ' vervangen door de woorden 'in de artikelen 77ter, 77quater en 77quinquies'.

Op zich weinig verrassend dus, maar het blijft natuurlijk wrang om vast te stellen dat artikel 380 Sw. blijft figureren in punt $\mathrm{I}^{\circ}$. De bedoeling daarvan was aanvankelijk natuurlijk dat het een kapstok zou bieden om mensenhandel aan te pakken in het buitenland, wat met de bijkomende opneming in punt $\mathrm{I}^{\circ}$ van de expliciete mensenhandelbepalingen die de wet van 2005 creëerde, niet langer nodig was.

\subsection{Na de nieuwe EU-richtlijn}

\subsubsection{Verdere verruiming strafbaarstelling mensenhandel}

De richtlijn verandert ten aanzien van het kaderbesluit 2002 niets aan het bewegingselement en dwang- of onvrijheidselement zoals vereist opdat gedrag door de lidstaten als mensenhandel zal moeten worden strafbaar gesteld. De wijzigingen aan de bestaande EU-minimumstrafbaarstelling doen zich uitsluitend voor met betrekking tot het derde vereiste bestanddeel ervan: de gerichtheid op uitbuiting. De uitbuitingsvormen (op EU-niveau tot op heden enkel in de seksuele en economische sfeer), worden uitgebreid en geherformuleerd. Volgens het voorstel van richtlijn omvat uitbuiting

'ten minste uitbuiting van prostitutie, andere vormen van seksuele uitbuiting, gedwongen arbeid of dienstverlening - bedelarij daaronder begrepen - slavernij en met slavernij vergelijkbare praktijken, dienstbaarheid, uitbuiting van strafbare activiteiten, en het wegnemen van organen'.

87 Koninkrijk België, De strijd tegen mensenhandel en mensensmokkel - Actieplan, Brussel, 2008.

88 In artikel 23. 
De verbreding naar het wegnemen van organen viel te verwachten. In het aanvankelijke kaderbesluit van 2002 was deze uitbuitingsvorm bewust achterwege gelaten. Ogenschijnlijk verbaasde dit, omdat die vorm wel figureerde in het VNmensenhandelprotocol van 2000. De EU wou evenwel een apart, volwassen rechtsinstrument in verband met orgaan- of weefseldiefstal en -transplantatie. Het voorstel van kaderbesluit dat daarover destijds werd gelanceerd, verdween echter van de onderhandelingstafel. De inhaalbeweging ten aanzien van de VN was daarmee eigenlijk enkel een kwestie van tijd, maar een zekerheid. De vraag naar de reële terreinmeerwaarde blijft evenwel (supra). Materieelstrafrechtelijk is België met de wet van 2005 - die er tegelijk toe strekte het VN-protocol te implementeren - ruimschoots op de verbreding naar het wegnemen van organen vooruitgelopen.

De verdere verbredingen hebben betrekking op uitbuiting van bedelarij respectievelijk strafbare activiteiten.

Voor de uitbuiting van bedelarij dient beklemtoond dat deze enkel exemplarisch figureert in de nieuwe minimumdefinitie, waarbij bedelarij als 'een' vorm van gedwongen arbeid of dienstverlening wordt gecatalogeerd. Het belang hiervan situeert zich dus eerder op interpretatief vlak, en staat overigens volkomen los van de huidige Belgische wetgeving, waarin er sprake is van mensenhandel indien het doel is ten aanzien van een persoon het autonome misdrijf 'exploitatie van bedelarij' te laten plegen. Los van wat eerder werd gesteld met betrekking tot de twijfelachtige meerwaarde van de Belgische bepaling ter zake, is het duidelijk dat, om aan de nieuwe richtlijn tegemoet te komen, hetzij de Belgische wetgever best de bestaande bepaling inzake mensenhandel met het oog op economische exploitatie herziet, door de notie 'tewerkstelling in omstandigheden die strijdig zijn met de menselijke waardigheid' eenvoudig te vervangen door de termen van de richtlijn (gedwongen arbeid of dienstverlening, met inbegrip van bedelarij), die op hun beurt uiteraard verder in de rechtspraktijk zullen moeten worden ingevuld en geoperationaliseerd (mogelijk leunend daarbij op uitgelokte minimuminterpretaties ter zake vanwege het Hof van Justitie in Luxemburg), hetzij de omzendbrief COL I/2007 wordt aangepast, in die zin dat er expressis verbis in wordt verwezen naar de minimale invulling vereist volgens de richtlijn (gedwongen arbeid of dienstverlening, met inbegrip van bedelarij).

Voor de exploitatie van strafbare feiten - los van de reële meerwaarde van inclusie van deze exploitatievorm onder mensenhandel - lijkt de Belgische wetgeving, met de wet van ro augustus 2005 , reeds geheel conform met de toekomstige richtlijn.

\subsubsection{Bewust gebruik van diensten geleverd door een slachtoffer van mensenhandel strafbaar?}

Het voorstel van richtlijn (artikel 15.4) roept de lidstaten verder op - ter preventie aan de vraagzijde - te overwegen over te gaan tot strafbaarstelling van het 'gebruik maken van diensten die het voorwerp zijn van uitbuiting [in de zin zoals minimaal omschreven in de richtlijn], in de wetenschap dat de betrokkene het slachtoffer is van mensenhandel'. Een nieuwe idee is dit geenszins. De strafbaarstelling in kwestie maakt al een tijdje opgang op diverse nationale niveaus, en ook de Raad van 
Europa suggereerde al eerder - in het Mensenhandelverdrag van 2005 - de bewuste gebruikmaking van diensten aangeboden door een slachtoffer van mensenhandel strafbaar te stellen. Moreel gezien lijkt zulke strafbaarstelling volkomen verantwoord, en overigens van geheel andere orde dan het Zweedse criminaliseren van ook de klant van de toestemmende prostituee. Vraag is enkel hoe gebruikmaking van diensten in het bewustzijn dat ze door een mensenhandelslachtoffer worden geleverd, kan worden geoperationaliseerd en of de wetgever in voorkomend geval de moed der rechtlijnigheid zal hebben door dergelijke bewuste gebruikmaking eveneens te criminaliseren waar het gaat om economische diensten of goederen geleverd of geproduceerd door slachtoffers van mensenhandel. Een harde implementatieverplichting vloeit dus niet uit de richtlijn voort, maar een debat dringt zich wel op.

\subsubsection{Niet-vervolging of -bestraffing slachtoffer}

Artikel 7 van het voorstel van richtlijn verplicht de lidstaten ook om, in overeenstemming met de grondbeginselen van hun rechtsorde, in de mogelijkheid [te voorzien] dat slachtoffers van mensenhandel niet worden vervolgd en bestraft wegens gedwongen betrokkenheid bij criminele activiteiten die een rechtstreeks gevolg is van een van de in artikel 2 van de richtlijn (waarin mensenhandel wordt gedefinieerd) bedoelde, jegens hen gepleegde handelingen.

Echt duidelijk is dit niet, gegeven de weinig precieze verwijzing naar artikel 2 van de richtlijn, waarin zowel het bewegingselement, het dwang- of onvrijheidselement als het exploitatiegerichtheidselement figureren. Kunnen de ten aanzien van slachtoffers gepleegde 'handelingen' zomaar worden gekozen uit elk van de elementen? 'Handelingen' jegens een slachtoffer kunnen bijvoorbeeld bestaan in het 'vervoeren' ervan (beweging), het chanteren ervan (dwang) of het effectief exploiteren ervan in bijvoorbeeld prostitutie (wanneer de gerichtheid op exploitatie zich vertaalt op reële exploitatie). Veel vragen, weinig heldere antwoorden. M.i. wordt - gezien de richtlijn op dit punt ook gewaagt van 'gedwongen betrokkenheid' - best alleen aangehaakt bij 'handelingen' die aanhaken bij het dwang- of onvrijheidselement.

Los van genoemde discussie, rijst verder natuurlijk de vraag hoe lidstaten - in casu België - de mogelijkheid tot niet vervolging en niet-bestraffing moeten of kunnen gestalte geven in het interne recht. Dat de richtlijn ter zake veel manoeuvreerruimte laat, is helder. Formeelstrafrechtelijk zijn de 'mogelijkheden' daartoe natuurlijk royaal voorhanden, bijvoorbeeld in de discretionaire beoordelingsbevoegdheid op OM-niveau. Vraag is alleen of zo'n ruime kapstok wel zal volstaan en of er geen behoefte bestaat aan heldere en voldoende rechtszekerheid biedende oplossingen op niveau van het materieel strafrecht. Voor België lijkt een mogelijk beroep op 'dwang' als schulduitsluitingsgrond alvast weinig rechtszekerheid te bieden, zodat ter overweging aan de wetgever lijkt te moeten worden gesuggereerd resoluut te opteren voor een strafuitsluitende verschoningsgrond. Daarbij wordt niettemin best toch eens nagedacht over mogelijk perverse effecten ten voordele van slachtoffers die niet echt bona fide zijn en zo hun eigen strafbare feiten verschoond weten. 


\subsubsection{Rechtsmacht}

Hiervoor werd al uitvoerig stilgestaan bij de Belgische extraterritoriale rechtsmachtbepalingen. Die gingen royaal de eisen van het kaderbesluit van 2002 te boven, zodat daarop niet eerder werd ingegaan. Nu de richtlijn aanzienlijk opschuift op dit punt, is het niettemin nuttig het acquis van het kaderbesluit mee te geven (artikel 6):

'Een lidstaat kan ertoe besluiten al dan niet slechts in specifieke gevallen of omstandigheden de rechtsmachtregels bedoeld in lid I, onder b en c, toe te passen indien het strafbare feit buiten zijn grondgebied is gepleegd.'

De punten b en c sloegen op de verplichting zich bevoegd te verklaren ten aanzien van mensenhandelfeiten gepleegd door eigen onderdanen (b) dan wel ten voordele van rechtspersonen met zetel op het eigen grondgebied (c). De beoordelingsvrijheid van lidstaten in verband met het vestigen van extraterritoriale rechtsmacht in die gevallen was evenwel totaal 'al dan niet slechts in specifieke gevallen'.

Artikel 9.3 van de nieuwe richtlijn gooit die vrijblijvendheid resoluut over boord. Voor eigen onderdanen moet iedere lidstaat de nodige maatregelen nemen om ervoor te zorgen dat, met het oog op de vervolging van (de poging tot, de medeplichtigheid aan, het aanzetten tot) mensenhandel buiten zijn grondgebied gepleegd, in rechtsmacht wordt voorzien, zonder daaraan bovendien de voorwaarde te verbinden dat de feiten strafbaar zijn op de plaats waar zij zijn gepleegd of dat de vervolging slechts kan worden ingesteld indien het slachtoffer aangifte heeft gedaan op de plaats waar het strafbare feit is gepleegd of na een aanklacht door de staat waar het strafbare feit is gepleegd. Voor België rijst er geen enkel probleem: de dubbele incriminatievoorwaarde en de voorwaarde van de voorafgaande klacht of aangifte werden reeds lange tijd geschrapt. Gelukkig heeft de EU er in de nieuwe richtlijn niet voor gekozen ook te verbieden dat de voorwaarde wordt gesteld dat de betrokkene in eigen land moet worden gevonden of aangetroffen.

\subsection{Besluit}

Met de Wet van Io augustus 2005 werd de Belgische mensenhandelwetgeving grondig herzien. De wet kwam voornamelijk tot stand om de tekortkoming in de begripsbepaling en -afbakening van mensenhandel (zoals die bestond na de Wet van I3 april 1995) te verhelpen en om te voldoen aan de minimumvereisten van het huidige internationale rechtsinstrumentarium. Ook op het terrein bestond er een grote vraag naar verduidelijking en verbetering van het wettelijke apparaat om de strijd tegen mensenhandel efficiënter te kunnen voeren.

De mensenhandelwet van 2005 kan om meerdere redenen toegejuicht worden. Voor het eerst wordt er in de Belgische wetgeving een duidelijk onderscheid gemaakt tussen de fenomenen mensenhandel en -smokkel, doordat mensenhandel (uitsluitend) strafbaar gesteld wordt in het Strafwetboek en de strafbaarstelling van 
mensensmokkel beperkt wordt tot de Vreemdelingenwet. Gelet op de fundamenteel verschillende aard van beide fenomenen (enerzijds mensenhandel als misdrijf tegen een persoon met een vaak ernstige aantasting van diens fysieke integriteit en anderzijds mensensmokkel als aantasting van de soevereiniteit van een staat en de daaraan gekoppelde noodzaak tot bescherming van het grondgebied), heeft de wetgever hiermee de meest logische keuze genomen.

De strafwet bevat vandaag dus een expliciete definitie van mensenhandel. Deze definitie omvat zowel mensenhandel met het oog op seksuele exploitatie als mensenhandel met het oog op exploitatie van arbeid of diensten en de orgaan- of weefseldiefstal en -transplantatie. Ten slotte kunnen ook Belgen voortaan erkend worden als slachtoffer van al deze vormen van mensenhandel.

Naast deze positieve punten, dienen er echter ook een aantal kritische bedenkingen bij de mensenhandelwet geformuleerd. Ten eerste vervangen de strafwetsbepalingen inzake mensenhandel de bestaande bepalingen inzake exploitatie van prostitutie (artikel 379, 380, paragraaf I, $I^{\circ}, 2,3$ en 4, I ${ }^{\circ}$ Sw.) niet. Het was logischer en eenvoudiger geweest deze artikelen te integreren in de nieuw ingevoegde strafbepalingen inzake mensenhandel. Ten tweede dient de seksuele exploitatiegerichtheid in de Belgische wet verbreed, onder meer tot volwassenenpornografie, maar in essentie tot elke vorm van seksuele exploitatie (zoals vereist dor het kaderbesluit van 2002 én bevestigd door de nieuwe richtlijn). Ten derde kan de omschrijving van mensenhandel met het oog op economische exploitatie ('een persoon aan het werk zetten of laten zetten in omstandigheden die in strijd zijn met de menselijke waardigheid') voor (bewijs- en interpretatie)problemen zorgen door het ontbreken van een wettelijke omschrijving van de notie 'menselijke waardigheid'. De nieuwe omzendbriefCOL I/2007 heeft lang geen absolute duidelijkheid gebracht, ook al lijkt het met de eerste praktijktoets op het niveau van de feitenrechter voorlopig nog mee te vallen. Best wordt, hetzij in de wetgeving zelf, hetzij minstens in de omzendbrief, uitdrukkelijker aansluiting gezocht bij de termen van de nieuwe richtlijn, althans bij wijze van minimuminvulling op het stuk van economische exploitatie (gedwongen arbeid of dienstverlening, met inbegrip van bedelarij). De uitbreiding van de wettelijke definitie tot mensenhandel met het oog op het laten plegen van exploitatie van bedelarij levert niet noodzakelijk een bijdrage in de strijd tegen mensenhandel, en wordt niet geëist door de richtlijn (die bedelarij als een vorm van gedwongen arbeid of dienstbaarheid, in de economische sfeer, catalogeert). Mensenhandel met het oog op het doen plegen van misdrijuen is intussen ook een hit op EU-niveau geworden door de definitieverbreding in de richtlijn.

De nieuwe richtlijn dwingt tot een duidelijk debat over de opportuniteit van het strafbaar stellen van de bewuste gebruikmaking van diensten geleverd door een slachtoffer van mensenhandel. In de seksuele sfeer zal daar weinig weerstand tegen zijn (ongeacht de moeilijkheden om een en ander te operationaliseren). Of de economische sfeer moet wordt meegenomen, zal het debat lastiger maken. Elke consument heeft daar wel boter op het hoofd, en we willen onszelf liefst niet te hard een spiegel voorhouden, toch? Interessant debat gegarandeerd dus. 
Verder moet worden overwogen een strafuitsluitende verschoningsgrond te introduceren voor misdrijven die slachtoffers onder dwang hebben gepleegd.

De ongetwijfeld meest te betreuren optie - ook na de nieuwe richtlijn - is de weglating van het dwang- of onvrijheidselement in de mensenhandeldefinitie. De wetgever is op dit punt nog strenger willen zijn dan de geldende internationale en Europese mensenhandeldefinities. Nochtans bestaat er algemene consensus dat de kern van mensenhandel net bestaat uit de dwang die op de betrokkene wordt uitgeoefend. Door het verwijderen van dit element uit de mensenhandeldefinitie wordt het door de wet gemaakte onderscheid met mensensmokkel in grote mate teniet gedaan. Bovendien wordt het belang van (de medewerking van) het slachtoffer in de strafprocedure hierdoor mogelijk gevoelig verminderd, wat de bescherming van dit slachtoffer niet ten goede komt.

Naast de weglating van het dwangelement, dragen ook andere factoren ertoe bij dat de bestaande verwarring tussen mensenhandel en -smokkel mogelijk zal blijven bestaan. Door de gelijkschakeling van de strafmaat voor mensenhandel en -smokkel wordt het wezenlijke verschil tussen beide fenomenen manifest miskend en bestaat het gevaar dat vooral de (gemakkelijk bewijsbare) mensensmokkeldossiers voor de rechtbank zullen gebracht worden, ten nadele van de zware mensenhandeldossiers en de daarin betrokken slachtoffers.

Ten slotte lijkt het wezenlijke onderscheid tussen mensenhandel en niet-problematische gevallen van mensensmokkel moeilijk verenigbaar met het inschakelen van de Interdepartementale Coördinatiecel, het IAMM en het CGKR in de strijd tegen dergelijke niet-uitbuitende vormen van mensensmokkel.

\section{$4 \quad$ Legalisering of (zelf)regulering van niet-uitbuitende vormen van exploitatie van geïnformeerd-consensuele seksuele dienstverlening als element van een hedendaags strafrechtelijk beleid inzake mensenhandel? ${ }^{89}$}

\section{I Inleiding}

Ook al zijn er sterke aanwijzingen dat de mensenhandel met bijvoorbeeld het oog op uitbuiting van arbeid of diensten of kinderhandel met het oog op illegale adoptie

89 Zie eerder: G. Vermeulen, 'Publiek-private samenwerking in de prostitutiesector. Zelfregulering op basis van kwaliteitsnormen ter voorkoming van mensenhandel en van overlast inzake prostitutie', in Overlast en de maatschappelijke aanpak ervan. Update in de criminologie, B. De Ruyver, C. Dewaele, M. Cools, E. De Wree, P. Hebberecht, T. Meeuws, L. Pauwels, P. Ponsaers, D. Reynders, E. Van den Herrewegen, T. Van der Beken, K. Van Heddeghem, S. Van Malderen, K. Verfaillie, G. Vermeulen (ed.), Mechelen, Gandaius, Wolters Kluwer, 2008, I45-I6I; G. Vermeulen, 'Zelfregulering via kwaliteitsnormen in de seksuele dienstensector?', in Betaalseksrecht. Naar regulering of legalisering van niet-problematische prostitutie?, G. Vermeulen (ed.), Antwerpen-Apeldoorn, 
in omvang toenemen, een niet-onbelangrijk deel van de mensenhandel houdt nog steeds verband met uitbuiting voor seksuele doeleinden. De link met de raam- en bordeelprostitutie- of escortsector en die van de productie van pornografie is in dat verband onvermijdelijk. Anders dan voor de escortsector en de pornosector - die nooit als bijzonder met mensenhandel verweven werden geacht (wellicht omdat er, terecht overigens, werd van uitgegaan dat het primair consensuele of zelfstandige activiteiten betreft) - is voor wat de raam- en bordeelprostitutiesector aangaat lange tijd aangenomen dat in de meeste gevallen nietsvermoedende vrouwen in de prostitutie werden gelokt en gedwongen, waarbij ze werden opgesloten, vernederd en geslagen. Vandaag klopt ook dat stereotiepe beeld niet meer. Dat bewijzen zelfs officiële studies naar bij slachtoffercentra geregistreerde slachtoffers van vrouwenhandel in ons land. Ook buitenlandse en illegale prostitue(e)s blijken in vele gevallen bewust en met voorkennis over de sector waarin ze zouden worden tewerkgesteld naar hier te komen. Daarmee is evenwel niet gezegd dat het een gemakkelijke keuze betreft en dat er naderhand niet mogelijk problemen van uitbuiting, onderbetaling of slechte werkomstandigheden rijzen. Dat laatste geldt overigens ook minstens in zekere mate voor escortwerk of diensten als pornoactrice of -acteur. Zelfs al betreft het werk waarvoor in regel aanvankelijk volkomen vrijwillig wordt gekozen, het risico dat de initiële toestemming op onvoldoende precieze informatie berustte in verband met de latere realiteit van het werk is immers ver van denkbeeldig. Zoals dat geldt voor werk in de pornoindustrie, verloopt ook escortwerk immers vaak in opdracht en dus onder de voorwaarden van een agentschap of bedrijf. Indien de realiteit van die voorwaarden in hoofde van de - aanvankelijk weliswaar toestemmende - betrokkene uiteindelijk alsnog verrassingen oplevert met betrekking tot bijvoorbeeld de aard of frequentie van te leveren prestaties, de controle daarop, de verloning ervan, de uitstap- of weigeringsmogelijkheden en de fysieke en gezondheidsomstandigheden waarin prestaties dienen geleverd (niet in het minst met betrekking tot onveilige seks), is dat uiteraard alsnog problematisch. Het risico op mensenhandel in die beide deelsectoren van de seksuele dienstensector blijft dus minstens tot op zekere hoogte bestaan, zeker nu bekend is dat legaliseringsoperaties met betrekking tot de uitbating in bordeel- of raamverband van niet-gedwongen prostitutie, wanneer, zoals in Nederland (infra), niet afdoende is voldaan aan bepaalde premissen en randvoorwaarden, een verschuiving naar de - niet-gereguleerde en veel meer verdoken escortbranche in de hand werken. Zodoende blijft uiteindelijk de gehele seksuele dienstensector - zelfs waar het, zoals in onze contreien, alvast initieel consensuele diensten betreft - nog steeds intrinsiek gekenmerkt door een potentieel verhoogde kwetsbaarheid voor uitbuiting en dus voor mensenhandel.

2007, Maklu, I5-26; G. Vermeulen (ed.), EU quality standards in support of the fight against trafficking in human beings and sexual exploitation of children. Exploratory study of the potential and feasibility of self-regulation and public-private co-operation, 2007, Antwerpen-Apeldoorn, Maklu, 443 p. G. Vermeulen, 'Naar een ISO 69-norm? Zelfregulering op basis van kwaliteitsnormen in de seksuele dienstensector als element van een hedendaags strafrechtelijk beleid inzake mensenhandel?', Panopticon, 2007.I, I-IO. 


\subsection{Vermenging beleidsdebatten seksuele dienstensector en mensenhandel gedateerd}

Vandaag dient echter vastgesteld dat de beleidsdebatten inzake de seksuele dienstensector en mensenhandel nog steeds te veel vermengd worden, in die zin dat de mensenhandelideologie het beleid inzake prostitutie en bij uitbreiding de gehele seksuele dienstensector domineert.

Iedere zin voor nuance ontbreekt, doordat het onrealistisch beeld in stand wordt gehouden dat zelfs het vervoeren, overbrengen of huisvesten van een persoon met het oog op de exploitatie van diens geïnformeerd-consensuele prostitutie of seksuele dienstverstrekking mensenhandel uitmaakt. Dit is manifest onjuist. De eigenlijke bestraffingsratio voor mensenhandel is namelijk gelegen in het dwang- of onvrijheidselement, ook al wordt dat door de mensenhandelwet van augustus 2005 jammer genoeg miskend. Volgens het bij die wet ingevoegde artikel 433quinquies Sw. is er immers, in afwijking van de vigerende internationale definitieconsensus inzake mensenhandel (zoals die onder meer blijkt uit het VN-Mensenhandelprotocol van november 2000, het EU-Kaderbesluit van juli 2002 en het Raad van Europa-Mensenhandelverdrag van mei 2005), sprake van mensenhandel zonder dat er een element van dwang, geweld, bedreiging, misleiding, fraude, misbruik van machtspositie, van kwetsbaarheid, of zo voort moet voorhanden zijn. Toestemming is irrelevant, zo heet het. Daarmee is ervoor gekozen om van mensenhandel te gewagen bij ontbreken van hét wezenskenmerk ervan. Precies in de gedwongen of onvrije uitbuiting, tewerkstelling, dienstbaarheid enzovoort schuilt nochtans de verantwoording voor de bestrijding van mensenhandel.

Bovendien is het gevaar reëel dat door beide debatten dusdanig met elkaar te vereenzelvigen, onder de noemer van de bestrijding van mensenhandel in wezen slag wordt geleverd tegen niet-gedwongen prostitutie (vanuit het morele dogma dat een vrije keuze voor seksuele dienstverlening intrinsiek onmogelijk is), tegen overlast (die met sommige vormen van prostitutie kan gepaard gaan) of tegen immigratie (omdat de exploitatie van prostitutie van derdelanders per definitie illegaal blijft, zoals in Nederland, zelfs na de opheffing van het bordeelverbod). Een quasiautomatische kwalificatie van de seksuele dienstensector als een broeihaard van mensenhandel en een daarbij horend repressief optreden op het terrein treffen echter voornamelijk de illegale prostitue(e)s of diegenen die anderszins de ongetwijfeld moeilijke maar geïnformeerde vrije keuze hebben gemaakt tegen betaling seksuele diensten of prestaties te leveren. Zij missen de zin voor nuance en precisie die noodzakelijk zijn voor een gerichte aanpak van de echte uitbuiters en organisatoren van gedwongen, onvrije seksuele dienstverlening.

\section{3 'Scheiding der markten' in de seksuele dienstensector?}

Precies die nuance en precisie ligt besloten in het beleidsmatig en op handhavingsvlak scheiden van de seksuele dienstensector in een malafide (mensenhandel) en een bonafide (geen mensenhandel) marktgedeelte. Kernvraag daarbij is in hoeverre maatregelen gericht op het reguleren, controleren en onder die voorwaarden 
strafrechtelijk gedogen van de bonafide - dat wil zeggen minder problematische want op geïnformeerd consensualisme en rechtsbescherming van de seksuele dienstenverstrekker gesteunde - dienstenmarkt enerzijds een gunstig effect kunnen sorteren in termen van preventie van mensenhandel en anderzijds een daadwerkelijke repressie kunnen bevorderen van het malafide marktsegment. Om te trachten een dergelijke 'scheiding der markten' tot stand te brengen, zijn er grosso modo twee theoretische opties: een heuse legalisering van de niet-uitbuitende en nietdwingende vormen van exploitatie (zeg maar: uitbating) van ontucht en prostitutie, of een loutere regulering en dito gedogen ervan.

\subsubsection{Legalisering}

De piste van legalisering van de niet-uitbuitende en niet-dwingende vormen van uitbating van seksuele dienstenverstrekking door meerderjarigen vertrekt vanuit de premisse dat minstens volwassenen de vrijheid hebben en moeten krijgen om voor zichzelf uit te maken of ze al dan niet tegen betaling seksuele diensten of prestaties willen leveren. Bijgevolg zou het runnen van een prostitutieonderneming, een escortbedrijf of een pornoproductiehuis zonder dat er sprake is van enige vorm van dwang, niet strafbaar mogen zijn en zou elk verbod ter zake moeten opgeheven worden. Een beleid dat de niet-uitbuitende (enkel op winst gerichte) exploitatie van geïnformeerd-consensuele seksuele diensten of prestaties niet strafbaar stelt en de meerderjarige seksuele diensten- of prestatieverstrekker dezelfde rechten verleent als andere werkende burgers, dient conceptueel een dubbel doel. Zulk beleid erkent niet alleen het fundamentele recht op zelfbeschikking van het individu, maar laat ook een effectievere aanpak van de echte uitbuiters en mensenhandelaars binnen het prostitutiemilieu toe, doordat een duidelijker onderscheid gemaakt wordt met en een helderder beeld verkregen wordt van de malafide kant van de sector. Hierin is meteen ook het wezenlijke theoretische voordeel gelegen van een legalisering in de strijd tegen mensenhandel met het oog op uitbuiting in de seksuele sfeer. Door werken in het bonafide marktsegment enerzijds te normaliseren (onder andere in de vorm van een statuut als werknemer of zelfstandige ${ }^{90}$ en de toekenning van sociale zekerheidsrechten vanuit een zogenoemd 'labourist'-visie) ${ }^{9 \mathrm{r}}$ en meteen ook bonafide uitbaters de rechtszekerheid te bieden die met legale bedrijfsvoering gepaard gaat, vergroot tegelijk de kans dat het malafide marktsegment én afslankt én zich makkelijker tegen de strafrechtelijke lamp laat houden. Op het voorlaatste Wereldcongres van de Association Internationale de Droit Pénal (Peking, september 2004) ${ }^{92}$ werd overi-

90 Betreffende de mogelijkheid van onderdanen van EU-lidstaten om zich in een andere EU-lidstaat als zelfstandige prostitue(e) te vestigen, dient gewezen op het ophefmakende Jany-arrest van het Europees Hof van Justitie (HvJ 20 november 200I, zaak C-268/99, Jany v. Nederland).

9I Zie o.a R. Haveman, Voorwaarden voor strafbaarstelling van vrouwenhandel, Deventer, Gouda Quint, I998, 246-248.

92 De aanbevelingen die terzake op het congres werden aangenomen, luiden als volgt: 'In order to enable law enforcement authorities to focus their attention on trafficking in persons for the purpose of sexual exploitation, it may be considered to be an option for some countries, respecting the fundamental principles of their own legal system and their own culture or religion, to decri- 
gens duidelijk dat een meerderheid van de congresgangers (die ook deelnamen aan het voorbereidend wereldcongres ter zake in Rio de Janeiro, april 2002) de mening was toegedaan dat er geen sprake kan zijn van mensenhandel wanneer volwassenen er vrij in toestemmen te worden aangeworven, vervoerd, overgebracht, gehuisvest, opgenomen of onder iemand anders' controle te worden gebracht met het oog op niet-uitbuitende prostitutie of pornografie. In een eerdere fase van de congresvoorbereiding (Noto, juni 200I) was in dat verband bovendien gepreciseerd dat, teneinde wetshandhavingsdiensten toe te laten hun aandacht te focussen op mensenhandel met het oog op seksuele exploitatie, landen ervoor kunnen kiezen om vormen van niet-gedwongen en niet-uitbuitende tewerkstelling in of organisatie van de prostitutie van volwassenen uit de strafwet te halen.

Het beleidsdebat over regulering of zelfs legalisering van de exploitatie van prostitutie is in vele landen gaande, buiten en binnen de EU. In oktober 2000 werd een legalisering doorgevoerd in Nederland. ${ }^{93} \mathrm{Nu}$ de opheffing van het bordeelverbod er sinds tien jaar in voege is, blijven tegenstanders van legalisering evenwel op de relatief magere resultaten van de operatie wijzen. Het Nederlandse model leverde inderdaad niet de verhoopte resultaten. ${ }^{94}$ Zonder een pleidooi in deze of gene richting te willen houden, is het echter nuttig erop te wijzen dat het beperkte succes van de Nederlandse legaliseringsoefening (die zoals eerder aangehaald zelfs gepaard is gegaan met zekere verschuivingseffecten van de voorheen illegale maar zichtbare bordeelprostitutie naar meer verdoken vormen van prostitutie, zoals escortwerk en appartementprostitutie) niet eigen lijkt te zijn aan legalisering an sich. Veeleer valt de minstens gedeeltelijke mislukking terug te voeren tot het niet vervuld zijn van bepaalde premissen en randvoorwaarden voor een succesvolle legalisering. Manifeste minpunten van de doorgevoerde opheffing van het bordeelverbod waren dat enkel een legaal kader werd gecreëerd voor het werken met prostitue(e)s uit EU-lidstaten, dat een effectieve strafrechtelijke aanpak van het blijvend-illegale marktsegment zeker in de beginjaren ruimschoots achterwege is gebleven en dat gemeenten - door de decentralisering van het vergunningenbeleid - ter zake al te gemakkelijk een nulbeleid (hebben) kunnen voeren. Het Nederlandse voorbeeld toont daarmee

minalize forms of non-coercive or non-abusive employment in or organisation of prostitution involving adults' (International Review of Penal Law, 200r, 887).

93 Wet van 28 oktober 1999 'tot wijziging van het Wetboek van strafrecht, enige andere wetboeken en enige wetten', Staatsblad I999, 464. Zie S. Bouzoumita en E. Van Acker, 'Bederf van de jeugd en de prostitutie', in G. Vermeulen (ed.), Strafrechtelijke bescherming van minderjarigen, AntwerpApeldoorn, Maklu, 20or. Voor een analyse van de voor- en nadelen en reacties van de prostitutiesector op legalisering van exploitatie van prostitutie in Nederland zie: T. Van Der Helm, 'Nieuwe regelgeving ten aanzien van prostitutiebedrijven en de gevolgen voor de gezondheidszorg voor de prostituees in Amsterdam', in A. Meheus, B. De Ruyver, K. Van Impe en M. Morival (eds.), Van opjaagbeleid tot gedoogbeleid. De aanpak van prostitutie in Nederland en Vlaanderen doorgelicht, Antwerpen, Maklu, I999, 93-95, respectievelijk N. CORBA, Beleid met betrekking tot prostitutiebedrijuen in Amsterdam, in A. Meheus, B. De Ruyver, K. Van Impe en M. Morival (eds.), o.c., I25-I36.

94 In 2002 werd een eerste evaluatie gemaakt van de effecten van legalisering van prostitutie in Nederland. De resultaten van deze studie toonden aan dat de verwachte terugval van criminele activiteiten binnen een gereguleerde prostitutie tot dan toe eerder beperkt was. Zie A. Daalder, Het bordeelverbod opgeheven, Prostitutie 2000-200I, WODC rapport 200, 2002. 
vooral aan dat voornamelijk de wijze waarop een legalisering wordt geconcipieerd en ingebed, cruciaal is voor het succes ervan. Even stap voor stap.

Ten eerste geldt de legalisering enkel voor EU-onderdanen, helemaal in de filosofie van het vrij vestigingsrecht voor deze laatsten wat betreft zelfstandige activiteiten binnen de EU. ${ }^{95}$ Voor 'werkzaamheden geheel of ten dele bestaande in het verrichten van seksuele handelingen met derden of voor derden' kan in Nederland geen tewerkstellingsvergunning verleend worden, zodat derdelanders werkzaam in de seksuele dienstensector per definitie in de illegaliteit verzeild blijven of raken. Conceptueel miskent de Nederlandse legaliseringsoefening daarmee niet alleen de realiteit (een groot deel van de prostituees in West-Europese landen zijn uit derde landen afkomstig) maar heeft zij natuurlijk in grote mate bij voorbaat haar eigen potentieel succes ondergraven. Kwatongen in de marge hebben beweerd dat het Nederlandse kabinet zich zeer goed van dit gebrek bewust was en dat de genomen beleidsoptie bewust zocht illegale derdelanders te viseren.

Ten tweede is een effectieve aanpak van de blijvend-illegale kantvan de prostitutiesector (lange tijd) ondermaats gebleven. Voorlopige evaluaties van de Nederlandse regeling leerden dat de politie zich vooral bezig hield met controles (in het kader van het bestuurlijk toezicht) in de gereguleerde sector, waardoor de capaciteit ontbrak om een controlerende en opsporende rol van belang te spelen inzake strafbare vormen van exploitatie van prostitutie buiten de gereguleerde sector. Nochtans is dat laatste essentieel om een systeem van regularisatie voor degenen die zich wel aan de vergunningsregels houden voldoende aantrekkelijk en dus globaal werkbaar te houden.

Ten slotte was er een probleem met de decentralisering van het beleid. Die decentralisering geeft op lokaal niveau aanleiding tot een totaal gebrek aan uniformiteit in het prostitutie- en dito vergunningenbeleid. Hoewel elke gemeente bij wet verplicht was een prostitutiebeleid te formuleren en minstens één bordeel op zijn grondgebied toe te laten, hebben vele gemeenten hun beleid zodanig geformuleerd dat nieuwe ondernemingen niet in aanmerking komen voor een vergunning. Onder het motto van overlastbestrijding of 'geholpen' door prostitutieonvriendelijke gemeentelijke bestemmingsplannen verbannen gemeenten bordelen ook niet zelden naar totaal onaantrekkelijke locaties. In een groot deel van Nederland kwam men daarmee uit op een verkapte nuloptie ten aanzien van legale bordelen. In een aantal gevallen neigde dit zelfs naar een oneigenlijk gebruik van bestuursbevoegdheden. In België zou een dergelijk handelen van gemeentelijke overheden via politieverordeningen die gebaseerd zijn op motieven van 'morele' openbare orde, zonder dat het aangetoond is dat er sprake is van een schending van de 'materiële' openbare orde (door een verstoring van de openbare orde, veiligheid of rust) wellicht met succes aangevochten kunnen worden bij de Raad van State. De intrekking eind 2006 van de vergunning van een derde van de seksuitbatingen op de Amster-

95 Zie het eerder aangehaalde arrest van het Europees Hof van Justitie van 20 november 20oI, zaak C-268/99, Jany $v$. Nederland. 
damse wallen ${ }^{96}$ na doorlichting van de uitbaters op basis van de wet Bibob (Bevordering integriteitsbeoordelingen door het openbaar bestuur) heeft overigens laten zien dat zelfs in steden als Amsterdam (die allerminst een nulbeleid voerden) het prostitutievergunningenbeleid soms wordt geïnstrumentaliseerd. Panden werden kennelijk vanuit een gewapend-bestuursaanpak gesloten (om zo gemakkelijk af te rekenen met uitbaters die verdacht worden van drugshandel en witwaspraktijken en waartegen het reguliere strafdossier te licht woog), zonder dat dit iets van doen had met een schending van de vergunningsvoorwaarden ten nadele van de prostitue(e)s die er waren tewerkgesteld.

In het huidige Belgische politieke klimaat is de piste van legalisering van nietuitbuitende vormen van exploitatie van geïnformeerd-consensuele seksuele dienstverlening wellicht te ver gegrepen. Hoewel in het federale regeerakkoord van juli 2003 een verbetering van de positie van de prostitue(e) was aangekondigd ('een einde zal worden gemaakt aan de sociale en juridische onzekerheid van de prostituees'), lijkt er vandaag geen politiek draagvlak voor legalisering van de uitbating van niet-problematische volwassenenprostitutie. De mensenhandelwet van augustus 2005, die zoals eerder aangehaald de exploitatie van prostitutie meer dan ooit in het mensenhandelbad heeft getrokken, bevestigt die teneur. Een tweede - juridisch - obstakel voor een betere bescherming van prostitue(e)s is het VN-Mensenhandelverdrag van 1950 dat door België, in tegenstelling tot Nederland, wel werd geratificeerd. ${ }^{97}$ Het verdrag weerspiegelt een zuiver abolitionistische visie met betrekking tot prostitutie en vereist dat elke vorm van exploitatie van prostitutie strafbaar wordt gesteld, ongeacht de vorm waarin deze plaats vindt en zelfs in geval van vrije (geïnformeerde) wilskeuze in hoofde van de prostitue(e). In ratificerende landen heeft dit tot de paradoxale situatie geleid dat het feit op zich van als prostitue(e) werkzaam te zijn niet strafbaar is, in tegenstelling tot alle aspecten die verband houden met het werken als prostitue(e), hetzij als zelfstandige (reclame maken, verhuur van kamers om seksuele diensten te leveren), hetzij onder gezag en leiding van een exploitant (exploitatie van prostitutie). ${ }^{9}$ Vandaar dat al jaren - ook in ons land - vanuit diverse hoeken gepleit wordt voor een aanpassing of eventuele opzegging van het VN-verdrag. Dit zou de weg vrijmaken voor een (inter)nationale decriminalisering van niet-uitbuitende en niet-dwingende tewerkstelling in en organisatie van prostitutie van volwassenen. ${ }^{99}$

96 'Amsterdams stadsbestuur sluit 155 bordelen. Vrolijk voortwippen op de walletjes', De Morgen, 4 december 2006.

97 Convention of 2I March 1950 for the Supression of the Traffic in Persons and of the Exploitation of the Prostitution of Others (UN Trafficking Convention) adopted by the General Assembly of the United Nations on 2 December 1949, United Nations Treaty Series, 1951, Vol. 96, No. 1342, 27 I.

98 G. Vermeulen, 'International trafficking in women and children', International Review of Penal Law, 200I, Jaargang 72,872 .

99 J. Meese, K. Van Impe, S. Vanheste, B. De Ruyver en W. Van Eeckhoutte, Trafficking in Human Beings. A Pilot Study with Poland and Hungary, Ghent, Research Group Drug Policy, Criminal Policy and International Crime, Ghent University, I998, 82. 


\subsubsection{Regulering}

Op korte termijn kan wellicht meer verwacht worden van loutere regulering van de sector, zonder de stap naar formele legalisering te zetten. Daarbij blijft het minder problematische want op geïnformeerd consensualisme en rechtsbescherming van de seksuele dienstenverstrekker gesteunde - lees: bonafide - marktsegment dus in de strafwet, maar wordt deze laatste niet gehandhaafd.

Marktscheiding in illegale sectoren is op zich allesbehalve nieuw - eerder gebruikelijk zelfs. Men denke bijvoorbeeld aan de drugsmarkt of aan die van de kinderarbeid. Zo wordt sinds jaren nu ook in België het loutere bezit voor eigen gebruik van cannabis, hoewel strafbaar, niet vervolgd voor zover het tenminste niet overigens problematisch is (doordat er minderjarigen geïmpliceerd zijn, er sprake is van overlast of dergelijke). Daarmee wordt op geïnstitutionaliseerde wijze een onderscheid gemaakt ten opzichte van andere drugsdelicten, die wel (een hogere) vervolgingsprioriteit krijgen. In verband met kinderarbeid, dat principieel verboden is, bewerkte de Internationale Arbeidsorganisatie (IAO) in I999 via haar belangrijke Verdrag nr. I82 tot uitbanning van de ergste vormen van kinderarbeid (onder meer in prostitutie, kinderpornografie enzovoort) zélf een onderscheid met andere, weliswaar ook strafbare, maar toch minder problematische en daarom minder urgent of absoluut uit te bannen vormen van kinderarbeid. In de zelfde zin maakt de zelfde IAO vandaag een bijzonder nuttig onderscheid tussen 'gedwongen arbeid' (forced labour), dat zij als kernelement ziet van mensenhandel, en andere schendingen van arbeids- of sociaalrechtelijke normen - van een lagere orde. In die zin is het - in de strijd tegen mensenhandel met het oog op seksuele uitbuiting - perfect legitiem bij voorrang in te zetten op het komaf maken met gedwongen ontucht of prostitutie, en in het belang daarvan de handhaving op andere, secundaire punten (goede zeden, illegale tewerkstelling en dergelijke) terug te schroeven. Een loutere kwestie van heldere prioriteitenstelling in het opsporings- en vervolgingsbeleid en degelijke afstelling met het gemeentelijk (administratief) sanctiebeleid.

\section{Overheidsregulering}

Tot op zekere hoogte hebben we op vandaag ook al reguleringstendensen in België op het stuk van de exploitatie van ontucht en prostitutie. Dit is inzonderheid het geval op het niveau van de gemeentelijke overheden, via allerhande (al dan niet via het administratief sanctiesysteem van artikel I igbis Nieuwe Gemeentewet gehandhaafde) gemeentelijke reglementen en politieverordeningen waarbij in functie van de openbare orde, rust en veiligheid 'bijkomende' strafrechtelijke normen aan de exploitatie van ontucht of prostitutie worden gesteld. Daarbij worden vooral normen opgelegd vanuit het oogpunt van overlastpreventie en goede zeden, die toelaten 'het prostitutieprobleem' te kanaliseren en voor de goegemeente verteerbaar te maken en te houden. Dergelijke reglementen voegen daarbij in theorie weliswaar strafbaarstellingen toe aan diegene die al vervat zijn in het Strafwetboek en die de exploitatie van ontucht en prostitutie überhaupt verbieden, maar doen dat vanuit een andere ratio. Daarom worden ze niet incompatibel geacht met het nationaal 
geldende strafrechtelijk verbod op exploitatie van ontucht en prostitutie. Een en ander werkt kennelijk omdat voor wat de in het Strafwetboek vervatte strafbepalingen aangaat de facto reeds in belangrijke mate een niet-vervolgingsbeleid geldt. Toch blijft dergelijke regulering erg diffuus, want zeer afhankelijk van de variaties en fluctuaties in gemeentelijk beleid en lokaal vervolgingsbeleid. Bovendien is ze ambigu, omdat ze aan de sectoractoren (seksuele dienstenverstrekkers, bordeel- en vitrine-uitbaters, pornoproducenten en -distributeurs) onvoldoende rechtszekerheid biedt. De eventuele gemeentelijke ontucht- en prostitutiespecifieke normen schuiven immers geen criteria naar voren in verband met aspecten die in wezen zien op bescherming van seksuele dienstenverstrekkers tegen uitbuiting of gedwongen arbeid (daarmee zouden gemeenten immers ingaan tegen normstellingen in het Strafwetboek zelf, bijvoorbeeld artikel 433 septies Sw. met betrekking tot verzwaarde mensenhandel) en die als zodanig door de sector vrij gemakkelijk en betrouwbaar kunnen worden nageleefd om zo vervolgingsvrij te blijven. Integendeel betreft het normen in de ruimere sfeer van de gemeentelijke bevoegdheden inzake openbare orde, rust en veiligheid, die op gemeentelijk vlak bovendien nogal discretionair en vrij willekeurig kunnen worden gehanteerd, gewijzigd en al dan niet (plots) gehandhaafd om - per definitie - allerhande andere redenen dan dat exploitanten zich aan uitbuiting of gedwongen arbeid in de seksuele dienstensfeer zouden bezondigen (daar ziet de gemeente niet op) of de ontucht- en prostitutiespecifieke gemeentelijke reglementaire of verordeningsbepalingen niet zouden naleven door bijvoorbeeld reële overlast te veroorzaken. Het bewust en gewild naleven van normen die onder meer inhouden dat enkel wordt gewerkt met geïnformeerd-toestemmende meerderjarigen, dat overlast wordt vermeden en dat de goede zeden niet worden verstoord, biedt exploitanten met andere woorden geen betrouwbare garantie dat ze niet het voorwerp zullen uitmaken van bijvoorbeeld een gewapend-bestuursaanpak (omwille van andere gemeentelijke agenda's), een raid inzake tewerkstelling van illegalen of zwartwerk, of zelfs heuse strafvervolging wegens exploitatie van (weliswaar consensuele) ontucht of prostitutie. Er blijft met andere woorden altijd wel een stok om mee te slaan, als men dat wil. Het organiseren van en werken in het bonafide segment van de seksuele dienstenmarkt wordt op zich dus niet consequent beloond, zelfs niet als men de ontucht- en prostitutiespecifieke bijkomende gemeentelijke normen naleeft - en daar wringt het schoentje.

\section{Zelfregulering}

De betere optie lijkt daarom dat het bonafide deel van de seksuele dienstensector zichzelf ontucht- en prostitutiespecifieke kwaliteitsnormen zou opleggen en zich tot controle en handhaving daarvan zou engageren, zonder daarin de speelbal te worden van wisselende gemeentelijke agenda's. Dit zou alvast helderheid en stabiliteit brengen van de normen die er in wezen écht toe doen om uitbuiting en gedwongen seksuele dienstenverstrekking - zeg maar: mensenhandel met het oog op seksuele exploitatie in de echte zin van het woord - te vermijden of tegen te gaan.

In een door de Europese Commissie gefinancierde studie (JLS/2005/AGIS/063) onder leiding van het Institute for International Research on Criminal Policy (IRCP) van de UGent, 
waarvan de resultaten begin 2007 werden gepubliceerd, ${ }^{\text {100 }}$ zijn voor een breed scala aan private sectoren/organismen in uiteenlopende activiteitensferen gedetailleerde sector- of activiteitspecifieke kwaliteitsnormen uitgewerkt ter preventie van mensenhandel en seksuele uitbuiting van kinderen. Het betrof onder meer normen voor de prostitutie-, escort- en pornosector. Bovendien werd daarvan nagegaan welk draagvlak ervoor zou (kunnen) bestaan in hoofde van diverse betrokken partijen (uitbaters of producenten, prostitue(e)s, escorts of pornoacteurs/-trices, klanten, politie/justitie, NGO's). De onderzoekshypothese was namelijk precies dat een systeem van zelfregulering binnen deze sectoren aan de hand van kwaliteitsnormen die alle betrokken partijen als waardevol, geschikt en voldoende bevinden om situaties van mensenhandel of seksuele uitbuiting van kinderen maximaal te voorkomen en uit te sluiten, nuttig zou kunnen zijn als alternatief voor een beroep op het traditionele (straf)rechtssysteem of op overheidsactoren en -controle in de ruimere zin. Het is immers - minstens theoretisch - plausibel dat zo de klassieke ambiguïteit die, zoals eerder beschreven, gepaard gaat met overheidsregulering en -controle van illegale of informele (economische) activiteiten, in grote mate kan worden vermeden. Bovendien heeft de - zelfs nabije - praktijk ook aangetoond dat zelfregulering in de seksuele dienstensector effectief veel potentieel heeft.

Als voorbeeld kan het voor enkele jaren in Antwerpen afgesloten 'Protocol betreffende de huurprijzen bij raamprostitutie' worden aangehaald. Het protocol was het resultaat van informeel overleg op sectorniveau: tussen prostitue(e)s, eigenaars van panden en uitbaters. Het doel ervan was tweevoudig: enerzijds het hanteren van een voor alle betrokken partijen aanvaardbare plafondprijs (en de daarbij horende criteria voor het vaststellen van de huurprijzen voor een werkruimte of vitrine en voor het gebruik van gemeenschappelijke ruimtes behorend tot een raamprostitutiepand), en anderzijds het bepalen van een maatstaf voor abnormaal profijt bij de verhuur, verkoop en ter beschikkingstelling van kamers of andere ruimtes met het oog op prostitutie. Dergelijke verkoop, verhuur of terbeschikkingstelling met de bedoeling een abnormaal profijt te realiseren is immers strafbaar overeenkomstig artikel 380 , par. I, $3^{\circ}$ Sw., dat destijds met de Mensenhandelwet van 1995 in het Strafwetboek werd ingevoegd. Met het protocol toonde de sector aan zelf in staat te zijn - met akkoord dus van de prostitue(e)s als belangrijkste ervaringsdeskundigen - tot aanvaardbare huurprijsafspraken te komen. Wat zouden politie en vervolgingsautoriteiten dan nog kunnen argumenteren dat huurprijzen die de protocolafspraken respecteren op abnormaal profijt zouden zijn gericht? Het voorbeeld illustreert dat afspraken op het niveau van de seksuele dienstensector, gecontroleerd door die sector, het potentieel hebben dat er zich een gedoogbeleid op ent, waarbij strafvervolging de facto voorbehouden wordt voor situaties waarin de protocolafspraken níet zijn nageleefd. De sector levert hier als het ware zelf de interpretatie van strafrech-

Ioo G. Vermeulen (ed.), EU quality standards in support of the fight against trafficking in human beings and sexual exploitation of children. Explorartory study of the potential and feasibility of self-regulation and public-private co-operation, 2007, Antwerpen-Apeldoorn, Maklu, $443 \mathrm{p}$. 
telijke concepten aan, toont aan tot bonafide gedrag bereid en in staat te zijn en wordt daarin verder gestimuleerd door het token van de niet-vervolging.

Het is met andere woorden plausibel dat zelfregulering en -controle en een daarop geënt strafrechtelijk gedogen van de bonafide - dat wil zeggen niet-problematische want op geïnformeerd consensualisme en rechtsbescherming van de seksuele dienstenverstrekker gesteunde - dienstenmarkt enerzijds een gunstig effect sorteren in termen van preventie van mensenhandel en anderzijds daadwerkelijke repressie bevorderen van het malafide marktsegment.

Concreet zouden kwaliteitsstandaarden voor de seksuele dienstenmarkt onder meer kunnen inhouden dat wanneer seksuele diensten of prestaties worden verleend of geleverd, dit geïnformeerd-consensueel gebeurt en enkel door volwassenen; dat voor diensten/lokalen waarvan de seksuele dienstenverstrekker gebruik maakt in voorkomend geval enkel all-in-huurprijzen worden gehanteerd zonder abnormale profijtmarge; dat aan seksuele dienstenverstrekkers een nette en veilige werkomgeving wordt geboden; dat de nodige verzekeringen zijn afgesloten; dat seksuele dienstenverstrekkers steeds recht hebben op adequaat beschermde seks, alsook op terugbetaalde regelmatige medische controle door een arts naar keuze (inclusief op HIV of andere SOA's); dat er geen sprake is van excessieve werkdagen of -uren, noch van onder- of wanbetaling; dat seksuele dienstenverstrekkers recht hebben op verlof, alsook het recht om zelf te beslissen of ze al dan niet diensten of prestaties leveren tijdens de menstruatie of de zwangerschap of wanneer ze een SOA hebben; dat zij tevens het recht hebben om bepaalde klanten/partners of bepaalde seksuele handelingen te weigeren (al kan dit natuurlijk tot verbreking van de samenwerkingsrelatie leiden); dat de uitbater, manager of eigenaar van een seksinrichting, vitrine of escortbureau of de pornopoducent minstens een functioneel-blanco strafregister heeft (te weten: minstens geen eerdere veroordeling heeft opgelopen voor seksuele delicten, seksuele uitbuiting, mensenhandel of andere misdrijven gepleegd in die context), en dat eventuele controles door bevoegde autoriteiten (politie, inspectiediensten, enzovoort) steeds actief zullen worden toegestaan.

Met het laatste wordt het belang beklemtoond dat kwaliteitsstandaarden zoals onderschreven en geafficheerd door bonafide exploitanten of producenten in eerste instantie zouden worden gecontroleerd via een controlemechanisme op het niveau van de seksuele dienstensector zelf. Daarbij dient deze evenwel absolute transparantie te bieden en zich open te stellen voor eventuele bijkomende controle ad hoc van overheidswege. Primaire overheidscontrole is in een systeem van zelfregulering en -controle, waarvan de adequatie prima facie niet in vraag dient gesteld omdat de sector er zelf economisch baat bij heeft, niet aan de orde. Meer zelfs: het is een contradictio in terminis. Bovendien dient in voorkomend geval te allen tijde vermeden dat, zoals eerder bleek uit voorlopige evaluaties van de Nederlandse regeling, de politie zich vooral zou bezig houden met controles in de gereguleerde sector, zodat het haar aan de capaciteit ontbreekt voor de noodzakelijke controle en opsporing ten aanzien van dat deel van de seksuele dienstensector dat zich (nog) niet als bonafide 
heeft gemanifesteerd door de kwaliteitsstandaarden nog niet te onderschrijven. De handhavingsfocus moet met andere woorden worden gericht op het malafide of nogniet-bonafide marktsegment.

Wil (zelf)regulering werkzaam zijn, dan moeten osporings- en vervolgingsautoriteiten met andere woorden bereid zijn niet op te treden tegen de exploitatie van volwassenenprostitutie of de productie en verspreiding van volwassenenpornografie, zelfs niet wanneer degenen die in genoemde context seksuele diensten verstrekken illegale verblijfsstatus hebben. Anders dan een legaliseringsscenario heeft een reguleringsscenario dat drijft op een geïnstitutionaliseerd conditioneel gedoogbeleid immers niet het nadeel dat de tewerkstelling van illegalen in een legaal kader een contradictie oplevert. In een blijvend illegaal maar gedoogd bonafide segment van de seksuele dienstenmarkt kunnen immers hoe dan ook geen juridisch geldige contracten tot stand komen, omdat die tegen de goede zeden ingaan.

Wel moet het natuurlijk van overheids- of vervolgingswege mogelijk blijven op te treden tegen manifeste overlast en tegen infiltratie van de bonafide seksuele dienstenmarkt door personen die deze als een vehikel (willen) gebruiken voor bijvoorbeeld het witwassen van opbrengsten van illegale activiteiten die, zoals dat ook het geval is voor de uitbuiting in mensenhandel, als problematisch gelden (georganiseerde misdaad, drugshandel, enzovoort).

Het is uiteindelijk natuurlijk vooral de sector zelf die het belang moet zien om bepaalde - geafficheerde - normen strikt na te leven. Daarmee kan deze een ethisch engagement nemen dat de sector alvast van het taboe verlost dat hij intrinsiek mensenhandel-gelinkt is. Bovendien moet een daadwerkelijke afwijzing van gedwongen seksuele diensten aan bonafide ondernemers toelaten om - op rechtszekere wijze buiten het strafrechtelijk vervolgingstracé te blijven. Ten slotte biedt kwaliteitscertificatie bijkomend economisch voordeel en potentieel.

Gegeven de criminaliseringstendens ten opzichte van personen die bewust gebruik maken van (onder meer seksuele) diensten geleverd door een slachtoffer van mensenhandel (zoals onder meer gepromoot in het Raad van Europa-Mensenhandelverdrag van mei 2005 en in de nieuwe EU-richtlijn), is het immers van toenemend belang dat consumenten van seksuele diensten (direct of via beeld), willen ze vervolgingsvrij blijven, vanwege de sector de garantie kunnen krijgen dat ze dat op ethisch verantwoorde wijze doen. Dat impliceert dat ze bewust moeten kunnen kiezen voor diensten die strafrechtelijk gezien voor henzelf risicoloos zijn. Dat geldt voor diensten die op geïnformeerd-consensuele en in behoorlijke rechts- en arbeidspositionele omstandigheden worden of werden geleverd - door manifeste niet-slachtoffers van mensenhandel dus. Consumenten doen dan best een beroep op diensten die gecertificeerd zijn als zijnde in overeenstemming met kwaliteitsstandaarden als hoger bedoeld. Vergelijkbaar met wanneer ze kiezen voor gecertificeerde 'eerlijke handel', voor een keurslager-label of een bedrijf met ISO-norm. 


\section{Doordacht migratiebeleid als onderdeel van een geïntegreerde aanpak van mensenhandel?}

\section{I Inleiding}

Illegale immigratie, mensensmokkel en mensenhandel zijn fundamenteel verschillende concepten. In de praktijk en ook beleidsmatig worden deze fenomenen echter voortdurend aan elkaar gelinkt. De gestegen aandacht voor het fenomeen van economische exploitatie is een belangrijke aanwijzing dat de mensenhandelproblematiek verder reikt dan de (traditionele) seksuele uitbuiting en dat er een onmiskenbaar verband bestaat met de massale arbeidsmigratie in onze huidige samenleving.

Sinds jaren vermelden Belgische beleidsdocumenten inzake mensenhandel uitdrukkelijk de noodzaak om de structurele oorzaken van het fenomeen aan te pakken. Een evaluatie van het Belgische mensenhandelbeleid vereist daarom een aanknoping met het migratiedebat. Dit debat hangt nauw samen met de vraag naar de concrete invulling van het vrij verkeer van werknemers binnen de uitgebreide EU.

Vooreerst wordt hierna bezien in welke mate er een link tussen migratie en mensenhandel bestaat. Vervolgens wordt een evaluatie gemaakt van het huidige migratiebeleid en de gevolgen hiervan voor de (bestrijding van) mensenhandel. Ten slotte worden verschillende beleidskeuzes in dit verband tegen elkaar afgewogen en wordt getracht na te gaan in hoeverre maatregelen op het vlak van migratie (kunnen of zouden) toelaten om mensenhandel doelgerichter en op een meer structurele wijze aan te pakken.

\subsection{Link tussen migratie en mensenhandel}

De meeste slachtoffers van mensenhandel zijn in feite migrantenarbeiders die op legale of illegale wijze naar een vreemd land trekken in een poging aan armoede of discriminatie te ontsnappen, hun levensstandaard te verbeteren of gewoonweg zelfs te kunnen overleven. ${ }^{\text {IoI }}$ De reële vraag in landen van bestemming naar goedkope en flexibele arbeidskrachten is een bijkomende aantrekkingsfactor. Voor vele migranten is hun reis dus een weloverwogen en bewuste (economische) keuze. Het is meestal pas bij aankomst in de landen van bestemming (of doortocht) dat de echte problemen beginnen. Zoals hierna zal worden verduidelijkt, houden deze vaak nauw verband met de illegale status van de betrokken immigrant in het land van bestemming of doortocht.

IoI Zie o.a. Global Commission on International Migration (GCIM), Irregular migration, state security and human security, September 2005, 33 p.; Anti-Slavery International, The migration-trafficking nexus, The Printed Word (UK), 2003, 27 p. 
De laatste jaren is niet op afdoende wijze tegemoetgekomen aan de steeds toenemende internationale vraag naar migrantenarbeiders. Het gebrek aan legale migratiemogelijkheden heeft vele immigranten genoodzaakt beroep te doen op diensten van smokkelaars. De risico's verbonden aan illegale smokkeldiensten zijn weliswaar veel groter dan voor andere (legale) diensten. De bewust en gewild aangegane dienstenovereenkomst inzake het vergemakkelijken of hulp bieden bij illegale immigratie ruimt veelal de plaats voor scenario's van mensenhandel, waarin van reële vrije wil en geïnformeerde weloverwogen keuzes geen sprake meer is.

Het risico op uitbuiting van illegale migrantenarbeiders hangt dus nauw samen met de illegale status van de betrokkene en de verhoogde economische, sociale en politieke kwetsbaarheid die hiervan het gevolg is. ${ }^{\text {Io2 }}$ Onderzoek naar mensenhandel bij illegale Oost-Europese vrouwelijke migrantenarbeiders heeft uitgewezen dat de fundamentele factor die bepaalt of men al dan niet verzeild geraakt in een netwerk van mensenhandel de mogelijkheid is tot legale migratie, gekoppeld aan een ontwikkeld sociaal netwerk. ${ }^{103}$

De reële link tussen het gebrek aan legale migratiemogelijkheden voor migrantenarbeiders en de verhoogde kwetsbaarheid voor mensenhandel is een eerste fundamentele vaststelling. De globalisering en toenemende deregularisering van de arbeid verhogen bovendien de kwetsbaarheid van (voornamelijk ongeschoolde) migrantenarbeiders. De informalisering van voorheen formele sectoren, zoals de constructie, landbouw en transport neemt in vele landen toe. De arbeid in dergelijke sectoren is goedkoop, vervangbaar en dus bijzonder kwetsbaar voor uitbuiting. ${ }^{104}$

\subsection{Het huidige migratiebeleid en de impact op de mensenhandelproblematiek}

\subsubsection{Noodzaak van een soepeler en gemeenschappelijk migratiebeleid}

Het Belgische (en Nederlandse) migratiebeleid en de daarmee verbonden mensenhandelproblematiek kunnen niet los gezien worden van de ruimere Europese context. De sociale en economische implicaties van de demografische veroudering en de voorspelde terugval van Europa's lokale bevolking beginnen in toenemende mate hun stempel op het migratiedebat te drukken. Demografische studies tonen aan dat, zelfs met het doorvoeren van maatregelen om meer mensen op de arbeidsmarkt

IO2 Zie ook: Global Commission on International Migration (GCIM), Migration in an interconnected world: New directions for action, October 2005, 34 .

I03 J. Davies, The role of Migration Policy in creating and sustaining trafficking harm, Migration Research Centre, University of Sussex, 2002, 3; IOM, Trafficking and Prostitution: The Growing Exploitation of Migrant Women from Central and Eastern Europe, Migration Information Programme, Budapest, I995, I2-I4.

I04 Sommige sectoren verhuizen naar plaatsen waar de arbeidsvoorwaarden werknemers het minst bescherming bieden. Andere sectoren worden informeel door het gebruik van contractanten of subcontractanten: Report of the Experts Group on Trafficking in Human Beings, 65 en $\mathrm{I}_{4} 6$. 
te krijgen en te houden, onze economieën steeds meer afhankelijk zullen worden van migrantenarbeiders. ${ }^{\text {105 }}$

De Europese Commissie heeft deze boodschap al enige tijd begrepen. Reeds in 2003 werd er op EU-niveau gepleit voor de noodzaak van arbeidsmigratie naar de EU, niet enkel als antwoord op de economische (cf. de Lissabon strategie ${ }^{\mathrm{I06}}$ ) en demografische realiteit maar ook om de toenemende illegale immigratie en de alarmerende betrokkenheid van de georganiseerde misdaad bij mensensmokkel en -handel aan te pakken. ${ }^{\text {107 }}$

Ook het recente Groenboek over het beheer van de economische migratie spreekt in dit verband klare taal: indien gemeenschappelijke criteria voor de toelating van economische migranten ontbreken, zal een groeiend aantal onderdanen van derde landen de EU illegaal binnenkomen zonder enige waarborg op regulier werk - en daarom op integratie in onze samenleving. Een duidelijke waarschuwing dus voor een toenemende mensensmokkel en mogelijks -handel indien de gepaste initiatieven zouden uitblijven. ${ }^{\text {108 }}$

\subsubsection{Een controlepolitiek op nationaal niveau}

Ondanks deze signalen hebben de regeringen van vele EU-lidstaten hun restrictieve migratiepolitiek voortgezet door het inperken van legale migratiemogelijkheden en het verstrengen van controles en procedures. In de media en binnen politieke kringen wordt (illegale) immigratie vaak omschreven als een bedreiging van de nationale soevereiniteit door het ondermijnen van de controle die staten dienen uit te oefenen over hun grenzen. ${ }^{\circ 09}$ Het belang van de overheid bij de perceptie door de burgers dat een fenomeen als migratie wel degelijk 'onder controle is', mag niet

I05 Om de omvang van de actieve bevolking alleen al in de I5 'oude' EU-lidstaten te stabiliseren, zou er tussen 2003 en 2050 een netto aanvoer van ongeveer 68 miljoen buitenlandse werknemers nodig zijn (IOM, World Migration 2003, Geneva, 2003, 245). Zie ook IOM, World Migration 2005, Geneva, 2005, I39-I52.

Io6 Op 20 maart 2000 werd op de Europese Raad te Lissabon de strategie bekendgemaakt die tot doel heeft van de EU de meest competitieve en dynamische op kennis gebaseerde economie in de wereld te maken.

I07 Commission of the European Communities, COM(2003) 336 final, Immigration, integration and employment, Brussels, 3 June 2003. Zie ook Commission of the European Communities, COM(2004) 508 final, First annual report on migration and integration, Brussels, I6 July 2004 en Commission of the European Communities, COM(2004) 4002 final, Area of Freedom, Security and Justice: Assessment of the Tampere Programme and future orientations, Brussels, 2 June 2004, 9-I0; Commission of the European Communities, COM(2005) 669 final, Policy Plan on Legal Migration, Brussels, 2I December 2005.

Io8 Commission of the European Communities, COM(2004) 8II final, Green Paper on the management of economic migration: an EU approach, Brussels, I7 January 2005, 4.

Io9 Global Commission on International Migration (GCIM), Migrants in the global labor market, September 2005, IO-II. 
onderschat worden. ${ }^{\text {II }}$ Bovendien past een restrictief immigratiebeleid (controlepolitiek) binnen de actuele wereldwijde strijd tegen terrorisme.

Er is een groeiende consensus dat een controlepolitiek illegale immigratie niet kan voorkomen. ${ }^{\text {III }}$ Het voor de hand liggende bewijs hiervan is het toenemende aantal illegale binnenkomsten in verschillende bestemmingslanden waar de laatste jaren een dergelijke politiek gevoerd werd. Bovendien liggen sommige van de factoren die migratie vorm geven buiten het bereik van directe overheidsinterventie, zoals globalisering, gewapende conflicten en breder wordende economische ongelijkheden tussen verschillende delen van de wereld. Een controlepolitiek heeft met andere woorden geen invloed op de fundamentele redenen voor illegale immigratie. Restrictieve migratieregimes lijken daarenboven onverenigbaar met het toenemende vrije verkeer van goederen, kapitaal en buitenlandse investeringen. ${ }^{\text {II2 }}$

Een restrictief immigratiebeleid wordt niet alleen meer en meer erkend als zijnde ineffectief in de strijd tegen illegale immigratie, maar leidt bovendien tot een toename van illegale smokkel en handel in migranten. Georganiseerde misdaad richt zich op elke markt waar de opportuniteit om winst te maken aanwezig is. Welnu, een restrictief migratiebeleid is de ideale voedingsbodem voor een illegale immigratiemarkt. Minder mogelijkheden tot legale migratie, in combinatie met sterke push and pull-factoren hebben migranten ertoe gebracht steeds wanhopiger middelen te gebruiken om te migreren en maken hen tezelfdertijd kwetsbaarder dan ooit voor mensenhandelaars. ${ }^{113}$

\subsubsection{Mensenhandel en de strijd tegen immigratie}

Het is ongetwijfeld zo dat de huidige illegale immigratie voor een groot deel gedreven wordt door de toenemende vraag binnen de EU naar migrantenarbeiders. Een arbeidsmigratiepolitiek die op rationele wijze aan deze vraag zou voldoen zou de noodzaak voor migranten om met mensensmokkelaars en -handelaars in zee te gaan gevoelig kunnen verminderen. Desondanks wordt mensenhandel dikwijls aangevoerd als een legitieme reden om het immigratiebeleid repressiever en strikter te maken.

De strijd tegen mensenhandel is in wezen gericht op de bescherming van personen tegen gedwongen of onvrije exploitatie. Het vrijwaren van de menselijke waardigheid houdt voor de overheid het recht en de plicht in om mensenhandel met alle mogelijke middelen te bekampen. Een dergelijk beleid heeft op zich niets te maken met de strijd tegen illegale immigratie die hoofdzakelijk ingegeven is door de

IIo Global Commission on International Migration (GCIM), Irregular migration, state security and human security, September 2005, II.

III Global Commission on International Migration (GCIM), Migrants in the global labor market, September 2005, I4-I5.

II2 IOM, World migration 2005, I4.

II3 Report of the Experts Group on Trafficking in Human Beings, I48. 
vrijwaring van nationale belangen. ${ }^{\mathrm{II} 4}$ Dat binnen het huidig restrictief migratiebeleid de bescherming van de menselijke waardigheid wordt voorgesteld als zijnde een reden om de grenzen te sluiten, kan derhalve niet overtuigen. ${ }^{\mathrm{I1}}$

\subsubsection{Nood aan een nuchter en doordacht migratiebeleid}

De strijd tegen mensenhandel maakt veelal een wezenlijk deel uit van nationale migratieprogramma's die ontegensprekelijk mede hun vertrekpunt vinden in de bescherming van de eigen welvaart. Een dergelijke politiek is echter vanuit twee opzichten misleidend. Ten eerste zijn de gesmokkelde illegale immigranten - ter wiens bescherming de migratiepolitiek zogezegd restrictief en repressief gehouden wordt - zelf de voornaamste slachtoffers doordat zij almaar kwetsbaarder worden voor echte uitbuiting, als gevolg van een almaar moeilijker wordende legale migratie en de illegale status die ermee samenhangt. Ten tweede, gelet op de stijgende afhankelijkheid van onze nationale economieën van een instroom van economische migranten, vormt een streng migratiebeleid net een wezenlijke bedreiging voor de eigen welvaart - ter behoud waarvan de grenzen volgens het huidige beleid strak dicht worden gehouden.

Voldoende en zwaarwichtige redenen dus om de de facto vermenging in het huidige beleid van de strijd tegen illegale immigratie en de strijd tegen mensenhandel aan de kaak te stellen. Er dient dan ook gepleit te worden voor een beleidsmatige scheiding van beide debatten. Dit neemt niet weg dat er op nuchtere wijze dient nagedacht over maatregelen op het vlak van migratie die niet enkel tegemoet komen aan de actuele economische en demografische noodwendigheden binnen de Europese Unie maar die tevens een positieve bijdrage kunnen leveren in de strijd tegen mensenhandel.

\subsection{Naar een soepeler migratiebeleid in de strijd tegen mensenhandel}

\subsubsection{Een restrictief migratieregime biedt geen oplossing}

Een versoepeling van het migratiebeleid vormt op zichzelf niet de ultieme oplossing voor mensenhandel. Niettemin zijn er gegronde redenen waarom het debat op zijn minst moet gevoerd worden en het huidige migratiebeleid aan een kritische evaluatie dient onderworpen.

De huidige migratiepolitiek is er vooralsnog niet in geslaagd illegale immigratie en mensenhandel aanzienlijk te verminderen. ${ }^{1{ }^{16}}$ De grote vraag naar buitenlandse arbeidskrachten heeft in de meeste EU-lidstaten nog niet geleid tot een soepeler

II4 Global Commission on International Migration (GCIM), Migrants in the global labor market, September 2005, Io.

II5 Vgl. J. Davies, l.c., 6.

II6 Global Commission on International Migration (GCIM), Migrants in the global labor market, September 2005, 3. 
economisch migratieregime. Het gegeven dat vele economische immigranten hun (desnoods illegale) immigratie slechts als een tijdelijke episode beschouwen in de overgang naar persoonlijke vrijheid en zekerheid wordt quasi volledig genegeerd.

Een verscherpt migratiebeleid werkt met andere woorden contraproductief in de strijd tegen mensensmokkel en -handel omdat geen rekening wordt gehouden met de 'migratieagenda' van vele economische immigranten. Meer nog, door een dergelijk beleid hebben de overheden in vele landen van bestemming zelf de uitbuiting van (illegale) arbeidsmigranten in de hand gewerkt.

\subsubsection{De voordelen van een soepeler migratiebeleid in de strijd tegen mensenhandel}

Een soepeler migratiebeleid zou het eigenbelang van de bestemmingslanden dienen. Studies tonen aan dat een invoer van economische immigranten noodzakelijk is om onze welvaart op hetzelfde peil te houden. De bestaande vraag naar migrantenarbeiders zal gevuld worden door illegale immigratie, tenzij de beleidsmakers dit proces op reguliere wijze beheersen. ${ }^{117}$ Economische immigratie heeft met andere woorden niet alleen het mogelijk potentieel om onze welvaart op peil te houden maar zou tevens kunnen bijdragen aan de beheersing van bestaande (illegale) migratiestromen. ${ }^{\mathrm{I} 18}$

Ten slotte zouden migranten zelf baat hebben bij meer legale migratiemogelijkheden. Een legaal statuut en een betere afdwingbaarheid van hun rechten zouden de kansen op uitbuiting door mensenhandelaars verminderen. Economische immigratie kan dus een indirecte bijdrage leveren aan de bestrijding van de uitbuiting van illegale immigranten in de zwarte economie en de mensenhandel. ${ }^{\text {II }}$

Indien een betere strijd tegen mensenhandel niet volstaat, dan zal wellicht het economische argument uiteindelijk de doorslag geven om een effectieve kentering in het migratiebeleid te weeg brengen. Een verminderde greep van de georganiseerde misdaad op de illegale immigratiemarkt en een betere bescherming van immigranten zal het logische gevolg zijn. Het pleidooi voor meer legale arbeidsmigratie kan dus gevoerd worden vanuit zowel economische (behoud van de eigen welvaart) als humanitaire (strijd tegen mensenhandel) overwegingen.

II7 Anti-Slavery International, o.c., I3.

II8 Zie o.a. de recente Resolutie van het Europees Parlement van 26 oktober 2005 (COM(2004) 8II). Zie ook Global Commission on International Migration (GCIM), Migrants in the global labor market, September 2005, 2 en Global Commission on International Migration (GCIM), Migration in an interconnected world: New directions for action, October 2005, 79-80.

II9 Resolutie van het Europees Parlement van 26 oktober 2005 (COM(2004) 8II). Zie ook Report of the Experts Group on Trafficking in Human Beings, 65. 


\subsubsection{Een stapsgewijze aanpak als deel van de oplossing}

In afwachting daarvan dient alvast een einde gesteld te worden aan de eerder aangehaalde instrumentalisering van mensenhandel in functie van het migratiebeleid. Bovendien zouden in het kadervan de preventieve aanpakvan mensenhandel een aantal structurele initiatieven kunnen opgezet worden om de toegang tot legale migratiekanalen te vergemakkelijken. Informatiseringcampagnes over legale arbeidsmigratie zouden hierbij zinvoller zijn dan campagnes met een louter afschrikkend of afradend oogmerk. ${ }^{120}$ Legale arbeidsmigratie op zichzelf biedt natuurlijk geen allesomvattende oplossing voor de mensenhandelproblematiek. Ook legale migranten kunnen het slachtoffer worden van mensenhandel. Er is daarom evenzeer nood aan een transparant en gereguleerd migratiebeleid dat voldoende aandacht besteedt aan het statuut en de rechten van de migrantenarbeiders en hun gezinnen. ${ }^{121}$ De exploitatie van arbeid moet ook aangepakt worden door regulering van die sectoren waar werknemers het meest kwetsbaar zijn voor uitbuiting. ${ }^{122}$

Migratie is in wezen niets meer dan een natuurlijke reactie van individuen op verschillende kansen en mogelijkheden binnen of buiten internationale grenzen. In elk geval ontsnappen we niet aan de noodzaak om het migratiedebat te openen en minstens na te denken over een helderder en soepeler migratiebeleid, niet enkel voor economische of demografische doeleinden maar ook om mensenhandel en mensensmokkel op een meer geïntegreerde wijze aan te pakken.

\subsection{Besluit}

Zowel het nationale als internationale beleid inzake de bestrijding van mensenhandel besteedt tot op vandaag slechts zeer beperkte aandacht aan de migratieproblematiek. In het preventieluik van het Belgische geïntegreerde mensenhandelbeleid zijn er enkele initiatieven die zich toespitsen op de structurele oorzaken van mensenhandel. Deze maatregelen bleven tot nog toe echter grotendeels beperkt tot het lanceren van sensibiliseringscampagnes in landen van oorsprong, doortocht en bestemming. Van een echte invloed van het actuele migratiedebat op het Belgische mensenhandelbeleid is vooralsnog geen sprake. Nochtans zijn er duidelijke en onmiskenbare aanwijzingen dat beide fenomenen nauw verbonden zijn.

I20 Global Commission on International Migration (GCIM), Irregular migration, state security and human security, September 2005, 27.

I2I Wat de status van migrantenarbeiders betreft zou alvast werk kunnen worden gemaakt van de ratificatie van de Conventie van de Verenigde Naties betreffende de Bescherming van de Rechten van alle Migrantenarbeiders en hun Families (I990). Dit Verdrag is de meest uitgebreide internationale norm met betrekking tot migrantenarbeiders. Voortbouwend op de principes van de ILO Conventies nr. 97 (I949) en I43 (I975) en de Universele Verklaring van de Rechten van de Mens tracht deze Conventie 'to extend human rights law to all migrant workers and their families throughout the entire migration process' en 'to prevent and eliminate the clandestine movements and trafficking in migrant workers and the employment of migrants in an irregular situation'.

I22 Zie Report of the Experts Group on Trafficking in Human Beings, I49-I5I. 
Op EU-niveau is er een sterke tendens ingezet om een meer realistisch migratiebeleid te voeren. De vraag tot versoepeling van de migratiepolitiek - zoals die de laatste tien jaar gevoerd werd - weerklinkt om verschillende redenen steeds luider. Een efficiëntere bestrijding van mensenhandel is er één van. Een evaluatie van het beleid in de meeste EU-lidstaten leert dat in werkelijkheid net het omgekeerde gebeurt. Een steeds repressiever en restrictiever migratiebeleid wordt aan het publiek voorgesteld als zijnde noodzakelijk om mensenhandelaars gemakkelijker te vervolgen en slachtoffers van mensenhandel beter te beschermen. De nadelige effecten van een dergelijk beleid krijgen minder tot helemaal geen media-aandacht, maar zijn des te meer voelbaar op het terrein.

De fenomenen illegale immigratie en mensenhandel kunnen niet zomaar gelijkgeschakeld worden. Het beleid inzake beide fenomenen mag dan ook niet vermengd worden. Niettemin hebben maatregelen op het vlak van migratie het potentieel om mensenhandel substantieel te verminderen door enerzijds de mogelijkheden tot legale arbeidsmigratie uit te breiden en anderzijds de sociale- en mensenrechten van immigranten in de landen van bestemming structureel te verbeteren. Op EUniveau worden dergelijke maatregelen al enige tijd gestimuleerd. ${ }^{23}$ Een plausibel argument dus om de kwetsbaarheid van immigranten voor uitbuiting door criminele personen/organisaties te verminderen en aldus een positieve bijdrage te leveren in de huidige strijd tegen mensenhandel.

\section{Aanbevelingen}

Om het wettelijke kader inzake mensenhandel nog logischer en overzichtelijker te maken, zou de wet van I3 april 1995 houdende bepalingen tot bestrijding van de mensenhandel en van de mensensmokkel de artikelen 379 en 380 Sw. niet meer als mensenhandel mogen beschouwen.

De invulling van het begrip seksuele exploitatie zou nog verruimd kunnen worden tot de exploitatie in de volwassenenpornografie (conform de internationale en Europese definities), naast de bestaande invulling als de exploitatie van de ontucht of prostitutie (artikel 379 en 380, paragraaf I en 4 Sw.) en kinderpornografie (artikel 383 bis, paragraaf I Sw.).

Een precieze definiëring binnen de wet van de notie 'menselijke waardigheid' (conform artikel 433quinqies, paragraaf $\mathrm{I}, 3^{\circ}$ ) zou bijdragen tot een duidelijker begrip van mensenhandel met het oog op economische exploitatie en zou bewijs- en

I23 Zie de eerder vermelde documenten zoals het Groenboek van de Europese Commissie van 2004 en de Resolutie van het Europees Parlement van 26 oktober 2005. Zie ook de 'Verklaring van Brussel' die in september 2002 tot stand kwam in het kader van de Europese Conferentie voor de Preventie en Bestrijding van Mensenhandel. Er werd toen reeds uitdrukkelijk bepaald dat 'de ontwikkeling van een bredere migratiepolitiek een substantiële bijdrage kan leveren om mensenhandel te verminderen en te voorkomen'. 
interpretatieproblemen ter zake kunnen vermijden. Best wordt, hetzij in de wetgeving zelf, hetzij minstens in de omzendbrief, uitdrukkelijker aansluiting gezocht bij de termen van de nieuwe richtlijn, althans bij wijze van minimuminvulling op het stuk van economische exploitatie (gedwongen arbeid of dienstverlening, met inbegrip van bedelarij).

Ondanks de ruimere omschrijving van mensenhandel dient er over gewaakt dat de strijd tegen mensenhandel toegespitst blijft op de echte gevallen van uitbuiting en niet gebruikt wordt om ongewenste (niet-uitbuitende) vormen van criminaliteit harder aan te pakken.

De uitbreiding van de wettelijke definitie van mensenhandel met het oog op het laten plegen van exploitatie van bedelarij blijft eigenlijk overbodig en levert geen meerwaarde in de strijd tegen mensenhandel. Dit geval zou uit de wettelijke definiëring van mensenhandel gelicht kunnen worden.

In de omzendbrief over het opsporings- en vervolgingsbeleid betreffende mensenhandel zou bepaald moeten worden dat door de gerechtelijke autoriteiten, niettegenstaande de wetswijzigingen, toch voorrang moet worden gegeven aan de gevallen van gedwongen of onvrije exploitatie.

Om het door de wet gemaakte onderscheid tussen mensenhandel en -smokkel niet teniet te doen, zou het dwang- of onvrijheidselement opnieuw moeten toegevoegd worden aan de wettelijke mensenhandeldefinitie, conform de ter zake geldende internationale en Europese mensenhandeldefinities.

De nieuwe richtlijn dwingt tot een duidelijk debat over de opportuniteit van het strafbaar stellen van de bewuste gebruikmaking van diensten geleverd door een slachtoffer van mensenhandel, inclusief wanneer het een slachtoffer van andere dan seksuele (zeg maar: economische) exploitatie betreft.

Verder moet worden overwogen een strafuitsluitende verschoningsgrond te introduceren voor misdrijven die slachtoffers onder dwang hebben gepleegd.

Om het wezenlijke verschil tussen mensenhandel en -smokkel ook in de praktijk door te voeren, zou de wet moeten voorzien in een verschillende strafmaat voor beide basismisdrijven.

Om te vermijden dat de verwarring tussen mensenhandel en -smokkel de facto gehandhaafd blijft, zouden de bevoegdheden van de belangrijkste (beleids)organen (de Interdepartementale Coördinatiecel, het Informatie- en Analysecentrum en het Centrum voor gelijkheid van kansen en voor racismebestrijding) moeten beperkt worden tot de strijd tegen mensenhandel en met dwang of uitbuiting gepaard gaande vormen van mensensmokkel (en zich dus niet mogen uitstrekken tot de volkomen consensuele variant van mensensmokkel, voorzien in artikel 77bis Vreemdelingenwet). 
Het ontwikkelen van een bonafide prostitutiemarkt kan een positieve bijdrage leveren in de strijd tegen mensenhandel door enerzijds de kwetsbaarheid voor uitbuiting te verminderen via een verbetering van de positie (statuut) van de prostitue(e) en anderzijds door de echte gevallen van uitbuiting en mensenhandel beter in beeld te brengen. De legalisering van niet-problematische (exploitatie van) prostitutie zou beide doelstellingen kunnen verwezenlijken maar is gelet op het huidige politieke klimaat weinig realistisch. De optie van zelfregulering via kwaliteitslabels biedt een waardevol alternatief indien dit gepaard gaat met een gedoogbeleid ten aanzien van de 'gereguleerde' prostitutiesector. In elk geval dient overwogen om het VN-Mensenhandelverdrag van 1950 aan te passen of eventueel op te zeggen om zo de weg vrij te maken voor een decriminalisering van niet-uitbuitende en niet-dwingende tewerkstelling en organisatie van volwassenenprostitutie.

Structureel lijkt een deel van de oplossing voor het mensenhandelprobleem gelegen in het royaal toelaten van arbeidsmigratie, inclusief in de sfeer van de seksuele dienstverlening. In afwachting daarvan dient er alleszins voor gewaakt dat het huidige mensenhandelbeleid niet in belangrijke mate een façade vormt voor een strenge aanpak van illegale migratie, overlastfenomenen of criminaliteitsvormen die zich bedienen van inwisselbare derdelanders. 